\title{
Determine Metrics and Set Targets For Soil Quality on Agriculture Residue and Energy Crop Pathways
}

Ian Bonner

David Muth

September 2013

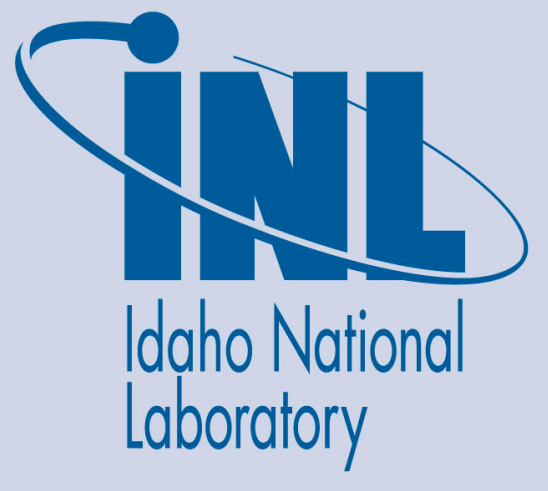

The INL is a U.S. Department of Energy National Laboratory operated by Battelle Energy Alliance 
INL/EXT-13-30485

\section{Determine Metrics and Set Targets For Soil Quality on Agriculture Residue and Energy Crop Pathways}

lan Bonner

David Muth

September 2013

Idaho National Laboratory
Idaho Falls, Idaho 83415

http://www.inl.gov

Prepared for the

U.S. Department of Energy

Assistant Secretary for Energy Efficiency and Renewable Energy Under DOE Idaho Operations Office

Contract DE-AC07-05ID14517 


\section{Idaho National Laboratory}

\begin{tabular}{|c|c|}
\hline $\begin{array}{l}\text { ID\#: } \\
\text { Type: D }\end{array}$ & $\begin{array}{l}\text { Completion Date: 9-30-2013 } \\
\text { Scheduled Completion: 9-30-2013 }\end{array}$ \\
\hline Milestone Title: & $\begin{array}{l}\text { Determine metrics and set targets for soil quality on agriculture residue and } \\
\text { energy crop pathways. }\end{array}$ \\
\hline Authors: & Muth D., Bonner I. \\
\hline $\begin{array}{l}\text { Project Name: } \\
\text { Project Leader: }\end{array}$ & $\begin{array}{l}\text { 1.1.1.2 - Sustainable Feedstock Production-Logistics Interface } \\
\text { J. Richard Hess }\end{array}$ \\
\hline Key Words: & Soil organic matter, soil quality, energy crops, residue removal \\
\hline
\end{tabular}

\section{EXECUTIVE SUMMARY}

There are three objectives for this project: 1) support OBP in meeting MYPP stated performance goals for the Sustainability Platform, 2) develop integrated feedstock production system designs that increase total productivity of the land, decrease delivered feedstock cost to the conversion facilities, and increase environmental performance of the production system, and 3) deliver to the bioenergy community robust datasets and flexible analysis tools for establishing sustainable and viable use of agricultural residues and dedicated energy crops. The key project outcome to date has been the development and deployment of a sustainable agricultural residue removal decision support framework. The modeling framework has been used to produce a revised national assessment of sustainable residue removal potential. The national assessment datasets are being used to update national resource assessment supply curves using POLYSIS. The residue removal modeling framework has also been enhanced to support high fidelity sub-field scale sustainable removal analyses. The framework has been deployed through a web application and a mobile application. The mobile application is being used extensively in the field with industry, research, and USDA NRCS partners to support and validate sustainable residue removal decisions.

The results detailed in this report have set targets for increasing soil sustainability by focusing on primary soil quality indicators (total organic carbon and erosion) in two agricultural residue management pathways and a dedicated energy crop pathway. The two residue pathway targets were set to, 1 ) increase residue removal by $50 \%$ while maintaining soil quality, and 2) increase soil quality by $5 \%$ as measured by Soil Management Assessment Framework indicators. The energy crop pathway was set to increase soil quality by $10 \%$ using these same indicators. To demonstrate the feasibility and impact of each of these targets, seven case studies spanning the US are presented. The analysis has shown that the feedstock production systems are capable of simultaneously increasing productivity and soil sustainability. 


\section{Idaho National Laboratory}

\section{Purpose and Scope:}

This project performs assessments and delivers decision criteria for the Sustainability Platform to meet goals and targets relative to following factors: soil quality, greenhouse gas emissions (GHG), nutrient use, and water quality. The assessments focus on agricultural residue and dedicated energy crop pathways through feedstock production and the interface with logistics systems. The Sustainable Production-Logistics Interface project is primarily focused on analysis tool development for environmental performance assessments. The logistics system interface is important because the specific harvest, collection, and local management practices for the feedstock are a primary factor in establishing sustainability performance.

This project is developing data and decision support tools ranging from the sub-field $(10 \mathrm{~m}-100 \mathrm{~m})$ to national scale. Work to date has focused almost exclusively on agricultural residues as the biomass feedstock. The focus moving forward is developing integrated landscape management strategies implementing multiple feedstocks within highly productive agricultural systems. The project is assembled to support the sustainability analysis elements critical to inform the interface between sustainable production and feedstock supply and logistics. Therefore, the project primarily supports Cross-cutting Sustainability and the Feedstock Supply and Logistics CTG. However, the design and development of highly integrated production systems that increase environmental performance also are being identified as having the potential to increase delivered feedstock quality to conversion processes through advanced blending and formulation strategies with in the supply and logistics systems. Because of this the project has the potential, with the support of multiple other OBP program elements, to impact the economics and sustainability of the conversion CTG pathways.

\section{Methodology and justification for targets}

This project utilizes an integrated data management and modeling framework to perform assessments and develop production system design concepts. The models used in the integrated model are the Revised Universal Soil Loss Equation 2 (RUSLE2), the Wind Erosion Prediction System (WEPS), Soil Conditioning Index $(\mathrm{SCl})$, and Daycent agroecosystem simulation model. RUSLE2 simulates daily changes in conditions including water and temperature dynamics within the soil to quantify the impacts of water erosion processes. It has been applied to a wide range of land management scenarios including cropland, pastureland, rangeland, and disturbed forestland. WEPS is a process-based daily time-step model that simulates how field conditions including soil water and temperature interact with wind forces including direction and magnitude. WEPS models a three-dimensional region to resolve mass balance equations and projects wind erosion impacts. WEPS has been used for cropland scenarios, including previous studies for evaluating the impacts of corn stover removal. The SCI utilizes parameters contributed by RUSLE2 and WEPS to provide qualitative predictions of the impact of land management practices on soil organic carbon. The $\mathrm{SCl}$ has been used for a broad range of soil quality assessments. Figure 1. Integrated computational model.Figure 1 provides a flow diagram of the computational methodology used to make each of the three models run within an integrated framework. By using a model integration framework, this methodology enables these models to be run over the large number of scenarios required to represent agricultural residue production in the US. Muth and Bryden, 2012 provides the technical details of the integrated methodology. The DAYCENT model quantifies soil organic carbon changes, long term crop yield impacts, and trace gas fluxes considering soil characteristics, management practices, and climate. 


\section{Idaho National Laboratory}

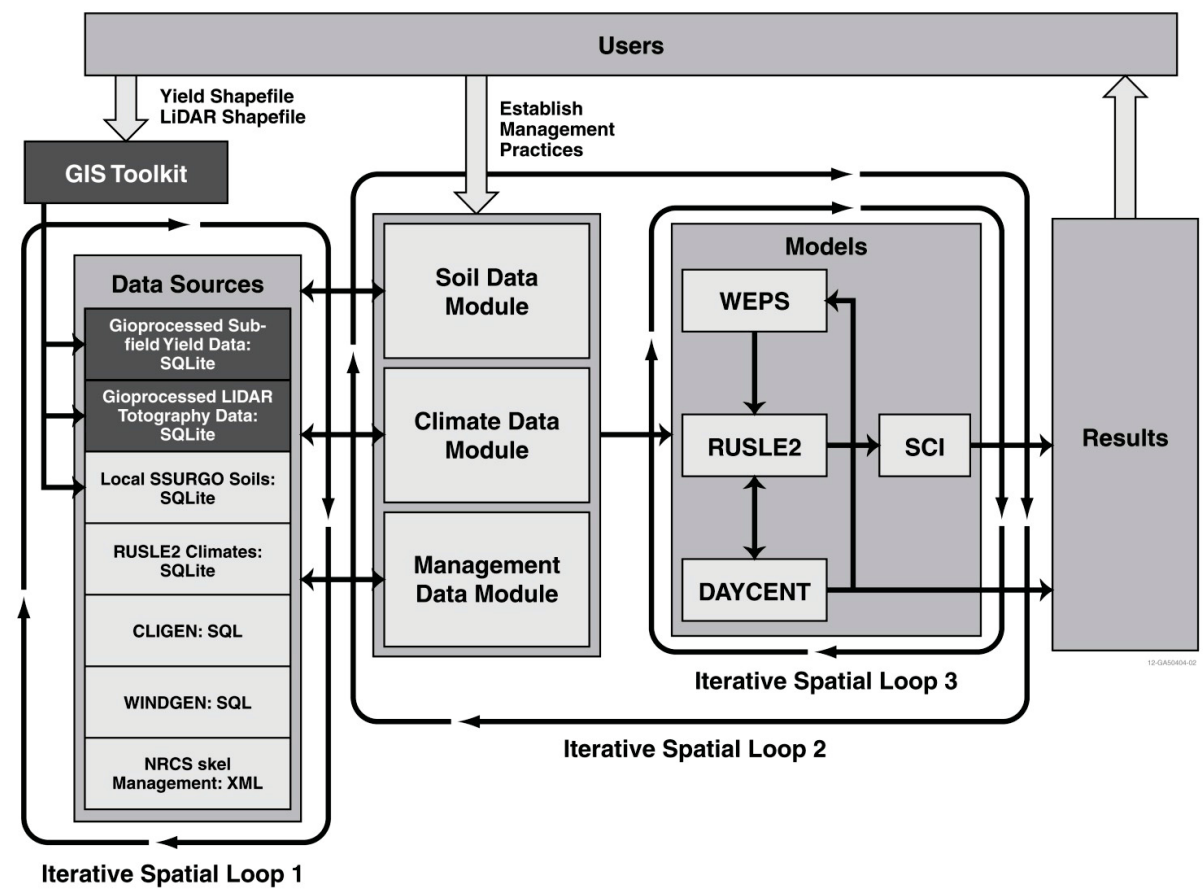

Figure 1. Integrated computational model.

The integrated modeling framework has been used to perform peer-reviewed assessments from the subfield ( $<10$ meter) to national scale. These assessments have incorporated best available data and assumptions and the analysis approach is currently beginning validation activities with the USDA Natural Resources Conservation Service (NRCS) as potentially supporting NRCS in developing conservation management plans for land managed with residue removal practices. The integrated modeling framework also continues to be calibrated and verified using field trial data from the Regional Feedstock Partnership Field Trial network. The calibration and verification activities have moved toward innovative agronomic management strategies and provide a key element for confidence in setting and achieving targets in support of the Sustainability Platform milestones. Furthermore the integrated model has been used extensively to date to perform peer-reviewed analyses for two enabling agronomic management strategies: cover crops and vegetative barriers.

The analysis approach has demonstrated the computational and data management capabilities to execute national scale analyses, and also to investigate spatial discretization at the field and sub-field scale. This multi-scale modeling approach coupled with calibration and verification activities with the Regional Feedstock Partnership and NRCS provide a viable platform for supporting Sustainability Joule milestone efforts. 


\section{Application to the FY13 Sustainability Dashboard}

This project has identified metrics and set targets for soil quality parameters related to agricultural residue and energy crop pathways for the FY13 Dashboard milestone. The project has worked collaboratively with the DOE Regional Feedstock Partnership program to identify appropriate and comprehensive soil quality indicators, and an assessment framework that can use the indicators to evaluate soil quality impacts of agricultural residue and energy crop management decisions. The indicators are then organized and selected to represent soil quality factors that BETO can monitor and quantitatively impact. The integrated analysis framework is used to apply progressive agricultural residue and energy crop management strategies and predict the potential long term impact of these strategies on the soil quality indicators. The simulated predictions are used to set targets for BETO in developing bioenergy feedstock production systems.

\section{Key Results}

\section{Defining Soil Quality}

Soil erosion is consistently identified as a critical process for soil quality (NRCS 1). Significant loss in productivity and soil quality will occur if soil erosion losses consistently exceed soil formation rates (NRCS 2). The USDA Natural Resources Conservation Service (NRCS) has developed standard approaches and tools for evaluating soil erosion levels to compare to established tolerable loss levels at the soil survey map unit scale. This project has incorporated the NRCS methods into the integrated framework, and all targets will include criteria that restrict simulated soil erosion levels to less than established tolerable soil loss levels.

In addition to soil erosion, soil quality is represented by a range of biological, chemical, and physical indicators of soil health. In collaboration with partners in the DOE Regional Biomass Feedstock Partnership it was determined that for this milestone the more appropriate and comprehensive soil quality evaluation approach is the Soil Management Assessment Framework (SMAF)(Andrews et al., 2004).

Table 1 below represents the soil quality indicators and scoring criteria that are included in the SMAF tool. 
Table 1. Soil quality indicators related to environmental, management, and productivity goals used in SMAF. Adapted from(Andrews et al., 2004).

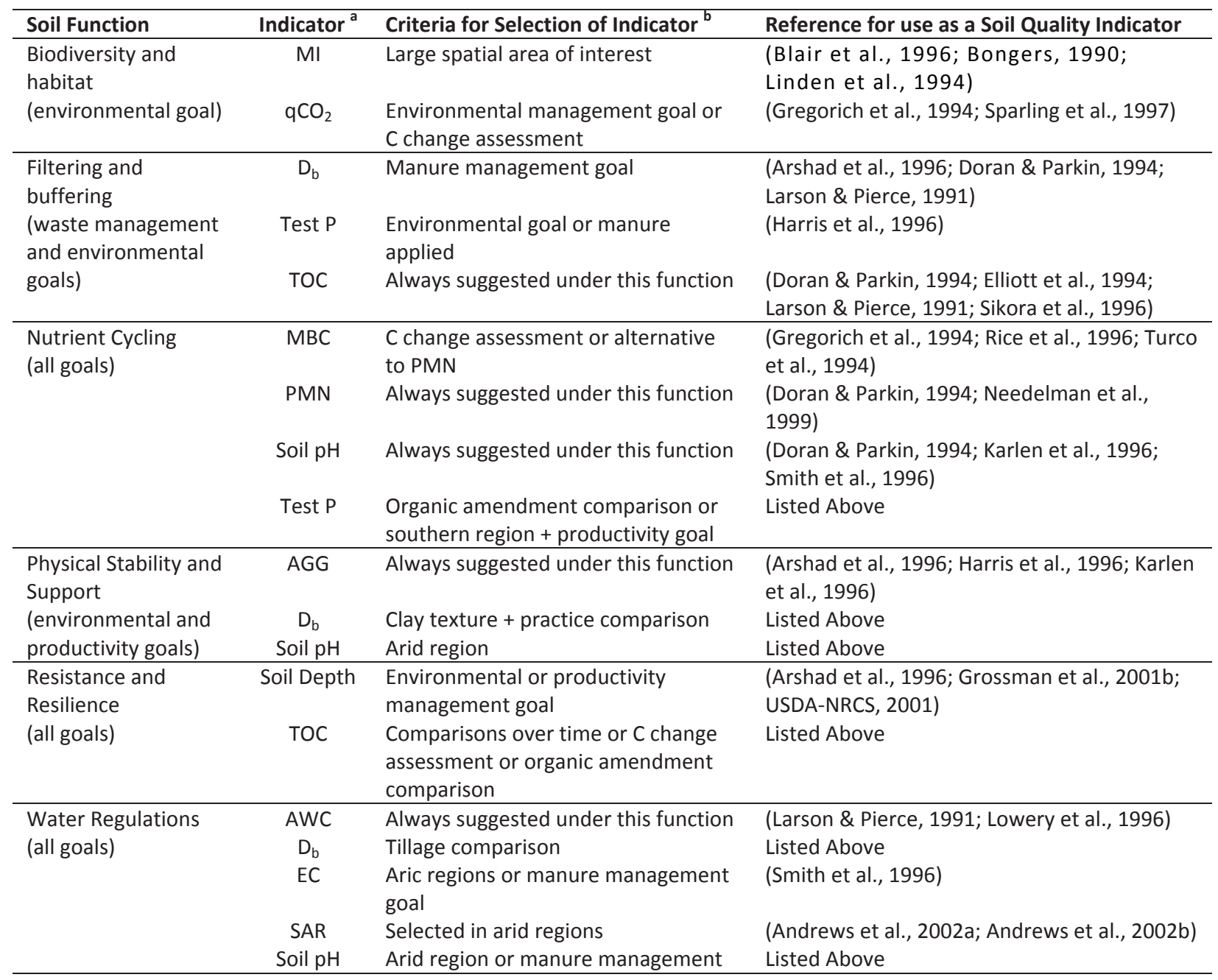




\section{Idaho National Laboratory}

or fertilizer comparison + water

quality.

a - MI, nematode maturity index (used as an endpoint measure instead of a MDS indicator, see text); $\mathrm{qCO}_{2}$, metabolic quotient (a proportion of soil respiration and microbial biomass); $D_{b}$, bulk density; test $P$, soil test $P$; TOC, total organic $C$; $\mathrm{MBC}$, microbial biomass $\mathrm{C}$; PMN, potentially mineralizable nitrogen (aerobic incubation); $A G G$, macroaggregate stability; AWC, available water capacity; EC, electrical conductivity; SAR, sodium absorption ratio.

b - When the stated criteria are met under a given function, the corresponding indicator is suggested as a potential minimum data set component.

Table 2. Algorithms and logic statements used for SMAF indicators. Adapted from (Andrews et al., 2004).

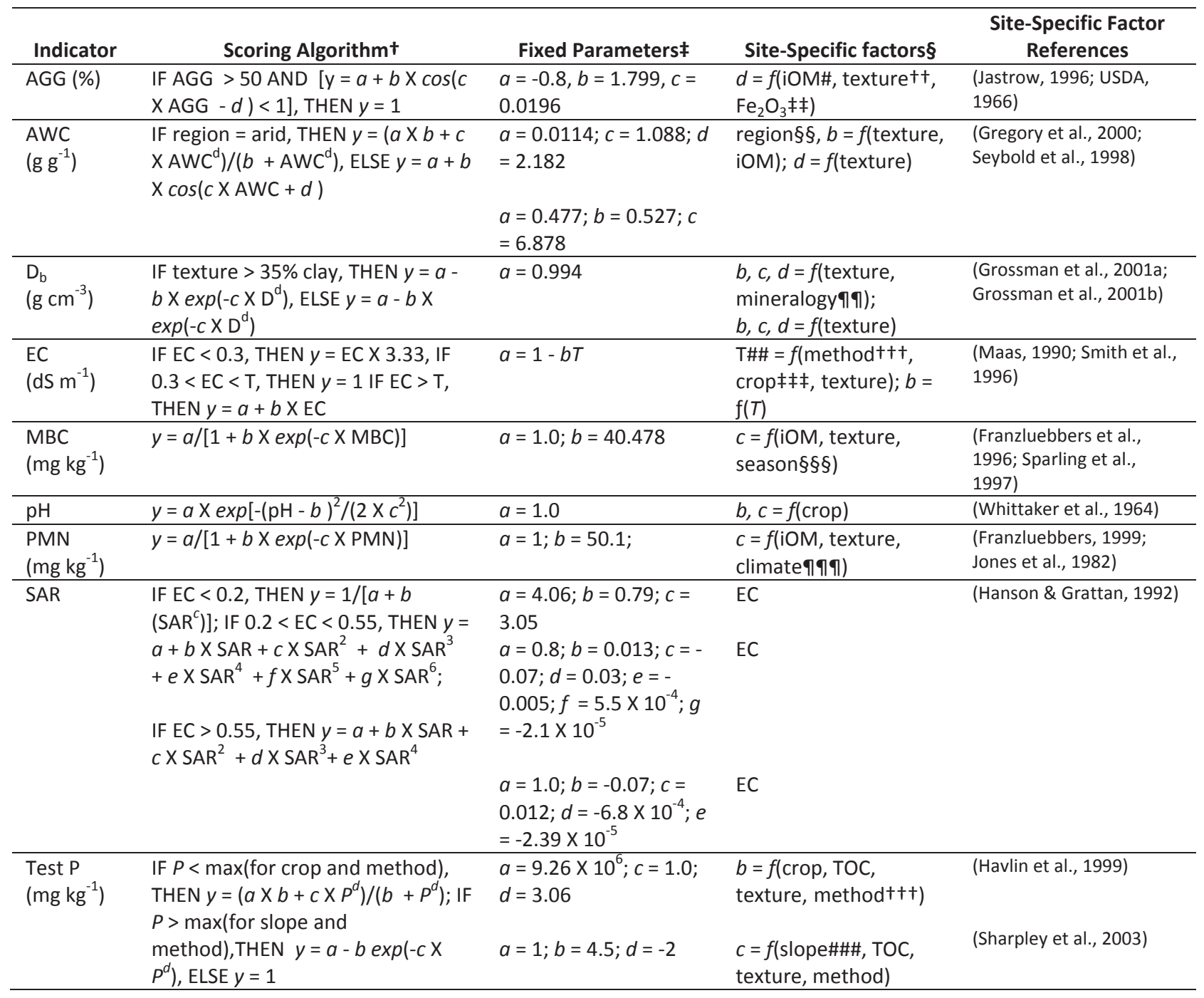




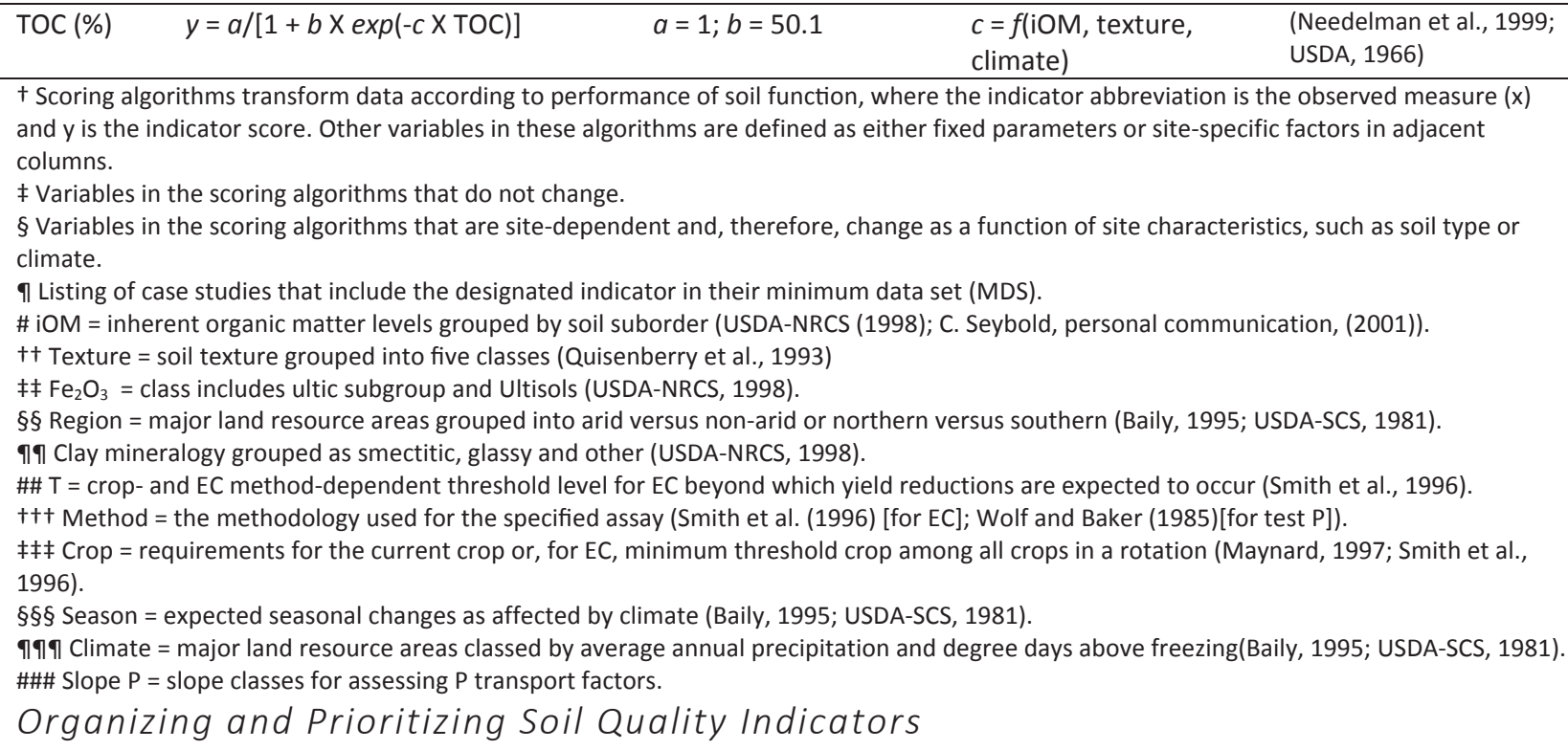

+ Scoring algorithms transform data according to performance of soil function, where the indicator abbreviation is the observed measure (x) and $\mathrm{y}$ is the indicator score. Other variables in these algorithms are defined as either fixed parameters or site-specific factors in adjacent columns.

$¥$ Variables in the scoring algorithms that do not change.

$\S$ Variables in the scoring algorithms that are site-dependent and, therefore, change as a function of site characteristics, such as soil type or climate.

ๆ Listing of case studies that include the designated indicator in their minimum data set (MDS).

\# iOM = inherent organic matter levels grouped by soil suborder (USDA-NRCS (1998); C. Seybold, personal communication, (2001)).

†† Texture = soil texture grouped into five classes (Quisenberry et al., 1993)

$\ddagger \ddagger \mathrm{Fe}_{2} \mathrm{O}_{3}=$ class includes ultic subgroup and Ultisols (USDA-NRCS, 1998).

$\S \S$ Region = major land resource areas grouped into arid versus non-arid or northern versus southern (Baily, 1995; USDA-SCS, 1981) .

ๆๆ Clay mineralogy grouped as smectitic, glassy and other (USDA-NRCS, 1998).

\#\# T = crop- and EC method-dependent threshold level for EC beyond which yield reductions are expected to occur (Smith et al., 1996).

+++ Method = the methodology used for the specified assay (Smith et al. (1996) [for EC]; Wolf and Baker (1985)[for test P]).

$\ddagger \ddagger \ddagger C$ Crop = requirements for the current crop or, for EC, minimum threshold crop among all crops in a rotation (Maynard, 1997; Smith et al., 1996).

$\S \S \S$ Season = expected seasonal changes as affected by climate (Baily, 1995; USDA-SCS, 1981).

ๆๆๆ Climate = major land resource areas classed by average annual precipitation and degree days above freezing(Baily, 1995; USDA-SCS, 1981).

\#\#\# Slope $\mathrm{P}=$ slope classes for assessing $\mathrm{P}$ transport factors.

Organizing and Prioritizing Soil Quality Indicators

While the SMAF database contains in excess of eighty indicators for determining soil quality as related to function, eleven of these indicators are of principal interest for communicating the achievement of landscape management targeted towards residue availability or the production of dedicated energy crops. Each of the soil quality indicators presented in

Table 1 can be categorized into locally managed, primary, or secondary indicators. These indicators play critical roles in determining the quality of a soil and thus help to define the operationally safe limits for management practices on soil function. In the context of methodology to meet the overarching objectives of sustainable crop residue production or dedicated energy crop integration, the sustainability impacts of the locally managed and secondary indicators are to be portrayed through the primary indicators.

Locally managed indicators include soil $\mathrm{pH}$, potentially mineralized nitrogen (PMN), and soil test phosphorus (test P), and are to a large extent determined by a land manager's agronomic practices. The relationship between each of these indicators is complex as the level of interaction between the three is high, and respect must be paid to each if management of one is to be undertaken. For example, soil pH impacts the availability of nutrients and activity of microorganisms which in turn limits a plant's productivity and the 


\section{Idaho National Laboratory}

soil's ability to cycle organic matter and minerals. Acidic nitrogen fertilizers lower the soil's $\mathrm{pH}$, and the potential to mineralize nitrogen from the soil's $\mathrm{N}$-pool is determined by $\mathrm{pH}$ dependent biotic and abiotic factors. Phosphorus management must be balanced with nitrogen management, as the ratio of $\mathrm{P}$ to $\mathrm{N}$ available to a plant heavily impacts plant productivity and pollution risks. Counterproductive feedback between these factors dictates that proper balancing is critical to maintain soil health and site productivity. Because of this, active management is required on a site specific basis.

Secondary indicators focus primarily on soil physical and chemical properties. As with the locally managed indicators, many of the secondary indicators interact with one another. In a broad sense, the physical properties of water stable aggregation (AGG), plant-available water holding capacity (AWC), and soil bulk density $\left(D_{b}\right)$ are appropriately discussed within the context of one another. Soil bulk density is the measure of a soil's mass within a specified volume, typically represented as $\mathrm{g} \mathrm{cm}^{-3}$, and is ;representative of soil compaction. Furthermore, depending on soil texture (composition of sand, silt, and clay) the bulk density of a soil will influence the soil's pore space which, in addition to its importance in gas exchange, is important in terms of infiltration rate and water holding capacity. An increase in soil bulk density decreases free air space in the soil, limiting gas exchange, root growth, and water relations. On the latter, water holding capacity is the measure of the quantity of water contained in a soil that is available for plant uptake (that is, not too tightly bound to soil particles due to an unfavorable fraction of micropores versus macropores as would be the case in a compacted soil). Reduction of a soil's plant-available water holding capacity increases the likelihood of plant desiccation in xeric conditions and may require additional management or resource use to maintain productivity. The stability of aggregates in a soil is indicative of the soil's organic carbon quantity and quality, as healthy soils with biotic decomposition of organics promotes the formation and stability of aggregates. The presence of aggregates in turn influences both the soil bulk density and water holding capacity, as large pore spaces are created that allow water infiltration and absorption of moisture into the aggregates themselves. Poor soil health related to these three indicators poses an interesting challenge, as poor bulk density, low aggregates, and low water holding capacity will result in poor stand production and increased rill and sheet erosion, but the most easily applied remedy to reducing soil compaction is tillage; which increases the soil's susceptibility to wind erosion. In whole, the proper management of these secondary indicators is ultimately reflected in soil erosion potential.

Soil chemical properties being classified as secondary indicators include electrical conductivity (EC), microbial biomass carbon (MBC), and sodium absorption ratio (SAR). The ability of a soil to conduct electricity is a common measure often used to describe soil physical properties (i.e., soil texture and moisture) and chemical characteristics (i.e., soil organic carbon, salinity, and pH). In a healthy soil system, electrical conductivity is greater in soils with smaller particles sizes (a greater fraction of clays versus sand) and thus inferences can be made to the soil's water holding capacity, pore space, and organic content. However, the sodium absorption ratio of a soil can have a great influence on soil EC, as sodium is highly conductive. A high sodium absorption ratio (a comparison of sodium ions present in a soil to those of calcium and magnesium) may develop in irrigated soils and is often associated with poor soil structure, inference with plant-water uptake, and reduce the soil's microflora. To this extent, the quantity of soil carbon derived from fungus and bacteria is reduced in a poor quality soil. In addition to a decreased pool of nutrients that would be provided by fungal biomass, the reduced microbial community will not provide the benefits of nutrient cycling and turnover (largely nitrogen availability that results from the breakdown of detritus by fungi) to the same magnitude as in a healthy soil system. 


\section{Idaho National Laboratory}

As discussed the soil quality indicators included in the SMAF are comprehensive, but they can be organized hierarchically for the targets developed in this report. The SMAF metrics can be organized into three categories as shown in Table 3. For the purpose of setting soil sustainability targets, two primary indicators have been chosen: soil erosion and total organic carbon (TOC). Although soil erosion is not handled by SMAF, all of the locally managed and secondary indicators discussed have an impact on a soil's erosion potential. By focusing sustainability goals on a soil erosion factor, the influence of an immense amount of soil quality indicators are built-in to the processes' objective, focusing primarily on the physical indicators of $A G G, A W C$, and $D_{b}$. Total organic carbon is similar in nature and largely encompasses a great deal of influence from soil biological and chemical properties, drawing impact from $M B C, p H, P M N$, test $P$, EC, and SAR. With these interactions noted and respected, the development of soil quality targets will rely strongly on the primary indicators and will incorporate the secondary indicators as a means of quantifying the longterm benefits of energy crop production.

Table 3. Organizing and prioritizing SMAF soil quality metrics.

\begin{tabular}{ccc}
\hline $\begin{array}{c}\text { Locally Managed Indicators } \\
\text { (Land manager has operational } \\
\text { controls) }\end{array}$ & Primary Indicators & Secondary Indicators \\
\hline $\mathrm{pH}$ & Soil Erosion (Not currently used in SMAF) & AGG \\
PMN & TOC & AWC \\
Test P & & D \\
& EC & MBC \\
& SAR & \\
\hline
\end{tabular}

\section{Baseline}

\begin{tabular}{|c|c|c|c|c|}
\hline Scenario(s) & $\begin{array}{c}\text { Reference } \\
\text { (if needed to describe } \\
\text { scenario) }\end{array}$ & Baseline Value & Unit & Year \\
\hline $\begin{array}{l}\text { Soil Quality for } \\
\text { Agricultural Residue } \\
\text { Pathways }\end{array}$ & $\begin{array}{l}\text { US DOE, 2011; Muth } \\
\text { et al., } 2012 .\end{array}$ & $\begin{array}{l}\text { At current soil quality levels the } \\
\text { top five residue producing states } \\
\text { can support an average removal } \\
\text { rate of } 2.06 \text { tons/acre. }\end{array}$ & Tons/acre/year & 2012 \\
\hline \multirow[t]{2}{*}{$\begin{array}{l}\text { Soil Quality for Energy } \\
\text { Crop Pathways }\end{array}$} & $\begin{array}{l}\text { US DOE, 2011; } \\
\text { Andrews et al., } 2004 .\end{array}$ & $\begin{array}{l}\text { Current \% SOM for each primary } \\
\text { soil type in each county in the US. }\end{array}$ & $\begin{array}{l}\% \text { SOM in top } 20 \mathrm{~cm} \text { of } \\
\text { soil profile. }\end{array}$ & 2012 \\
\hline & & $\begin{array}{l}\text { Current SMAF score by soil and } \\
\text { management unit. }\end{array}$ & $\begin{array}{l}\text { SMAF reporting: \% of } \\
\text { potential for crop } \\
\text { production }\end{array}$ & \\
\hline
\end{tabular}

Target(s) 


\section{Idaho National Laboratory}

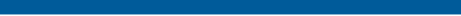

\begin{tabular}{|c|c|c|c|c|c|}
\hline & $\begin{array}{c}\text { (if needed to } \\
\text { describe scenario) }\end{array}$ & & & & to Baseline \\
\hline $\begin{array}{l}\text { Soil Quality for } \\
\text { Agricultural Residue } \\
\text { Pathways }\end{array}$ & $\begin{array}{l}\text { US DOE, 2011; } \\
\text { Muth et al., } 2012 . \\
\text { English et al., } 2012 .\end{array}$ & $\begin{array}{l}\text { Increase } \\
\text { sustainable } \\
\text { removal rate } \\
\text { average by } 50 \% \\
\text { while maintaining } \\
\text { soil quality. }\end{array}$ & Tons/acre/yr & 2017 & $\begin{array}{l}\text { Management practices will } \\
\text { be developed and tested } \\
\text { that maintain primary soil } \\
\text { quality metrics and facilitate } \\
\text { a } 50 \% \text { increase in removal } \\
\text { rates. }\end{array}$ \\
\hline $\begin{array}{l}\text { Soil Quality for } \\
\text { Agricultural Residue } \\
\text { Pathways }\end{array}$ & $\begin{array}{l}\text { US DOE, 2011; } \\
\text { Muth et al., } 2012 . \\
\text { English et al., } 2012 . \\
\text { Andrews et al., } \\
2004 .\end{array}$ & $\begin{array}{l}\text { Increase SMAF } \\
\text { soil quality scores } \\
\text { by } 5 \% \text { while } \\
\text { maintaining BTU } \\
\text { projected residue } \\
\text { removal rates. }\end{array}$ & $\begin{array}{l}\text { SMAF reporting: } \\
\% \text { of potential for } \\
\text { crop production. } \\
\text { Primary metrics } \\
\text { are soil erosion } \\
\text { less than } 1 / 2 \mathrm{~T} \text { - } \\
\text { value and SOM } \\
\text { increase by } 5 \% \text {. }\end{array}$ & 2017 & $\begin{array}{l}\text { The management practices } \\
\text { associated with the previous } \\
\text { soil quality target to increase } \\
\text { removal rates can also be } \\
\text { applied with current BTU } \\
\text { projected removal rates to } \\
\text { positively impact primary soil } \\
\text { quality metrics. }\end{array}$ \\
\hline $\begin{array}{l}\text { Soil Quality for Energy } \\
\text { Crop Pathways }\end{array}$ & $\begin{array}{l}\text { US DOE, 2011; } \\
\text { Andrews et al., } \\
\text { 2004. Karlen and } \\
\text { Muth, } 2013 .\end{array}$ & $\begin{array}{l}\text { Increase SMAF } \\
\text { soil quality scores } \\
\text { by } 10 \% \text { by } \\
\text { integrating } \\
\text { energy crops into } \\
\text { the productive } \\
\text { row crop } \\
\text { landscape. }\end{array}$ & $\begin{array}{l}\text { SMAF reporting: } \\
\% \text { of potential for } \\
\text { crop production. } \\
\text { Primary metrics } \\
\text { are soil erosion } \\
\text { less than } 1 / 2 \mathrm{~T} \text { - } \\
\text { value and SOM } \\
\text { increase by } 10 \% \text {. }\end{array}$ & 2017 & $\begin{array}{l}\text { This target will identify the } \\
\text { soil characteristics and } \\
\text { management practices } \\
\text { within primary production } \\
\text { agriculture where significant } \\
\text { soil quality benefits can be } \\
\text { achieved from converting } \\
\text { practices to energy crop } \\
\text { production. }\end{array}$ \\
\hline
\end{tabular}

\section{Detailed Methodology and Justification}

The following discussion provides analysis results justifying the targets developed through this report. The analyses focus on the top five residue producing states to explore the impact of management strategies required to achieve the developed targets. The down selection to the top five residue producing states is reasonable for three reasons: 1 ) These five states represent $65 \%$ of the residue available nationally, 2 ) they provide $85 \%$ of the residue available at a minimum economic threshold of 1.0 short ton/acre county average removal rate, and 3 ) they represent the locations where sufficient data has been available to verify the analysis results and management practices used in this analysis.

The analysis methodology used for these targets is discussed in detail in Muth and Bryden, 2013 and Muth et al., 2012. The tool used is the Landscape Environmental Assessment Framework (LEAF). More information on LEAF can be found at www.inl.gov/LEAF, and the LEAF open source code project can be found at http://code.google.com/p/leaf-tools/. 


\section{Idaho National laboratory}

\section{Target: Increase sustainable removal rate average by $50 \%$ while maintaining soil quality.}

A primary challenge for developing crop residues as a bioenergy feedstock is managing removal in a way that, at a minimum, maintains soil quality. This target focused on maintaining soil quality while improving system level economics through management practices that increase the sustainable residue removal rates. Figure 2 shows the county average removal rates for 2012 from the Billion Ton Update at a farm gate price of $\$ 80 /$ dry ton. This high price was chosen to economically motivate participation in residue harvest. The values in Figure 1 provide the baseline for this target and analysis.

Four additional scenarios were generated for the top five residue producing states. These are shown in Table 4. The first scenario couples the LEAF analyses to the Billion Ton Update projections. LEAF analyses calculate the maximum sustainable residue removal rates without considering economics. The LEAF tools and methodology were used to establish sustainable removal rate potential for the Billion Ton Update Analysis. The Billion Ton Update then applied the economic constraints resulting in the residue potential listed in Table 4 for scenario 1. Removing the economic constraints the total sustainable removal potential is shown in scenario 2 in Table 4. This represents the baseline values for sustainable residue removal potential without considering economic constraints.

Scenario 3 in Table 4 represents a scenario where cover crops management strategies are used in conjunction with residue removal practices. There is significant work ongoing to develop cover crop agronomic practices, particularly in geographic locations further north. For this analysis the assumption is made that the cover crop agronomics will be solved for in the geography included. The use of cover crops increased the average sustainable removal rate across the five top residue producing states from 2.06 short tons/acre to 3.15 short tons/acre. This management strategy alone has the potential to achieve the first agricultural residue pathway target developed in this report. 


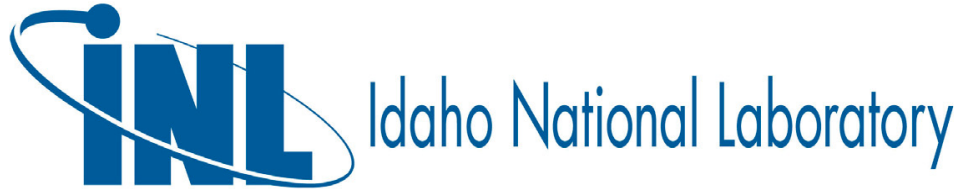

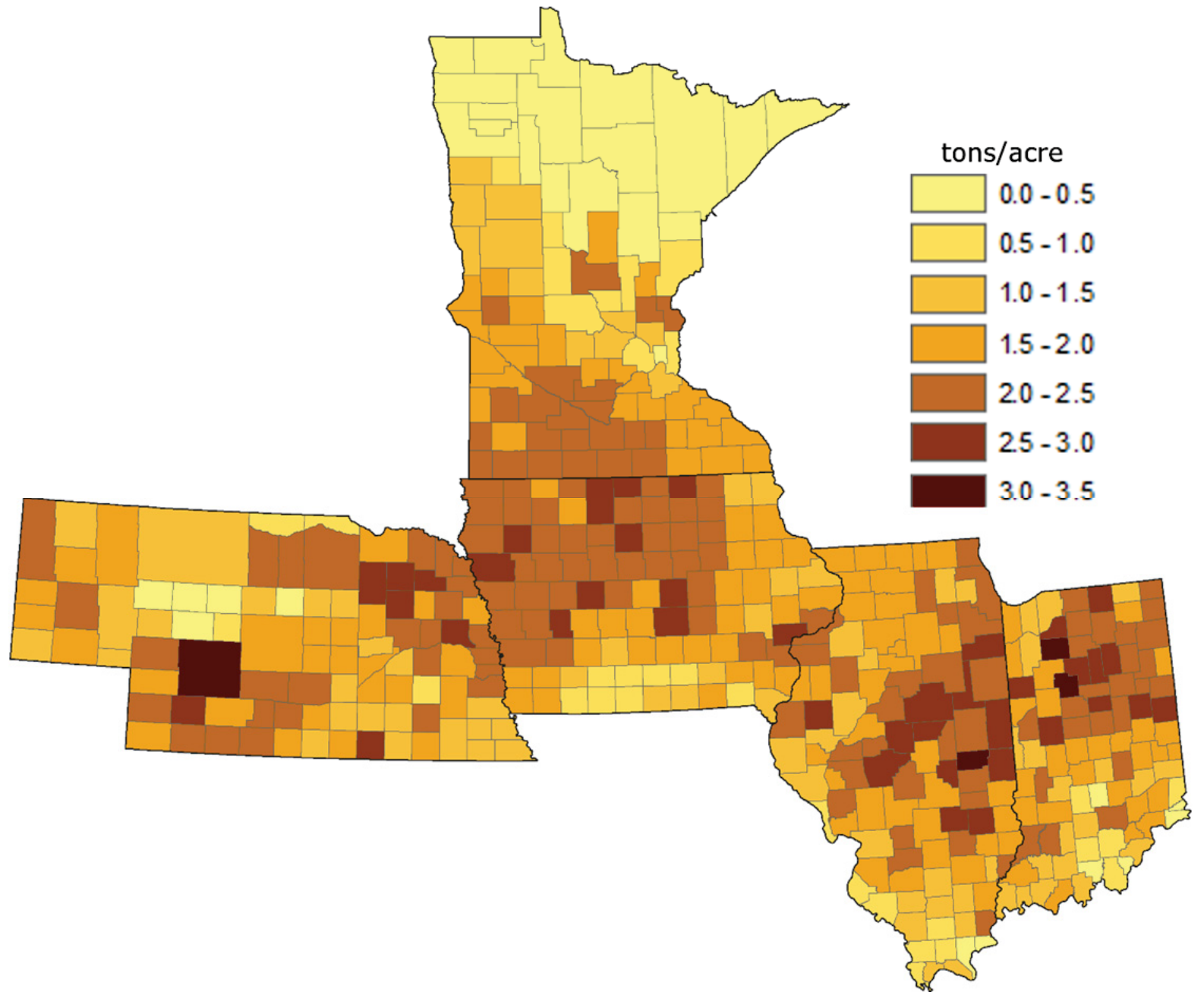

Figure 2. Billion Ton Update corn stover removal rates by county at $\$ 80 /$ dry ton farm gate price. Includes top 5 residue producing states.

Table 4. Five top residue producing states analysis of sustainable residue availability under different management regimes.

\begin{tabular}{lcc}
\hline \multicolumn{1}{c}{ Analysis Scenario } & $\begin{array}{c}\text { Total Residue Available } \\
\text { (short tons) }\end{array}$ & $\begin{array}{c}\text { Average Sustainable Removal Rate } \\
\text { (short tons/acre) }\end{array}$ \\
\hline 1: BTU 2012 @ \$80/dry ton corn stover & $62,556,100$ & 1.85 \\
\hline $\begin{array}{l}\text { 2: LEAF total sustainable residue (no cover crop, } \\
\text { no vegetative barriers, standard tillage } \\
\text { practices) }\end{array}$ & $106,055,706$ & 2.06 \\
\hline $\begin{array}{l}\text { 3: LEAF total sustainable residue (cover crop, no } \\
\quad \begin{array}{l}\text { vegetative barriers, standard tillage } \\
\text { practices) }\end{array}\end{array}$ & $160,225,948$ & 3.15 \\
\hline $\begin{array}{l}\text { 4: LEAF total sustainable residue (cover crop, } \\
\quad \text { vegetative barriers, standard tillage } \\
\text { practices) }\end{array}$ & $185,405,658$ & 3.65 \\
\hline $\begin{array}{l}\text { 5: LEAF total sustainable residue (cover crop, } \\
\text { vegetative barriers, no tillage practices) }\end{array}$ & $214,055,099$ \\
\hline
\end{tabular}


Scenario 4 in Table 4 includes cover crop strategies and the use of vegetative barriers in conjunction with residue removal. The use of vegetative barriers primary supports a decrease in soil erosion that can increase sustainable residue removal rates. Vegetative barriers also provide an opportunity to strategically incorporate perennial energy crops into the productive row crop landscape to increase SOC level on stressed and low quality soils. This scenario maintains soil quality while increasing average sustainable removal rates from 2.06 to 3.65 short tons/acre in the top five residue producing states.

The final scenario used to develop this target is scenario 5 in Table 4. Cover crop, vegetative barrier, and no tillage management strategies are used. This combination of management strategies increases the average sustainable residue removal rate for the top five residue producing states from 2.06 short tons/acre in the baseline to 4.32 short tons/acre. The development of these three strategies provides the fundamental basis for establishing the target of "Increasing sustainable removal rate average by 50\% while maintaining soil quality."

Figures 3-5 show the geographic impact of these strategies. Figure 3 represents current tillage practices and includes maps that show the removal rate impact of four potential combinations of including cover crop and vegetative barrier management strategies. Cover crops (lower left, Figure 3) and vegetative barriers (top right, Figure 3) independently have a significant impact on increasing sustainable removal rates, but they have the greatest impact in combination (lower right, Figure 3). Figure 4 shows the geographic impact of these strategies using more invasive tillage practices. The impact of the advanced management practices is still positive, but a shift to no tillage practices in conjunction with cover crop and vegetative barrier practices has the most impact, as seen in Figure 5. 


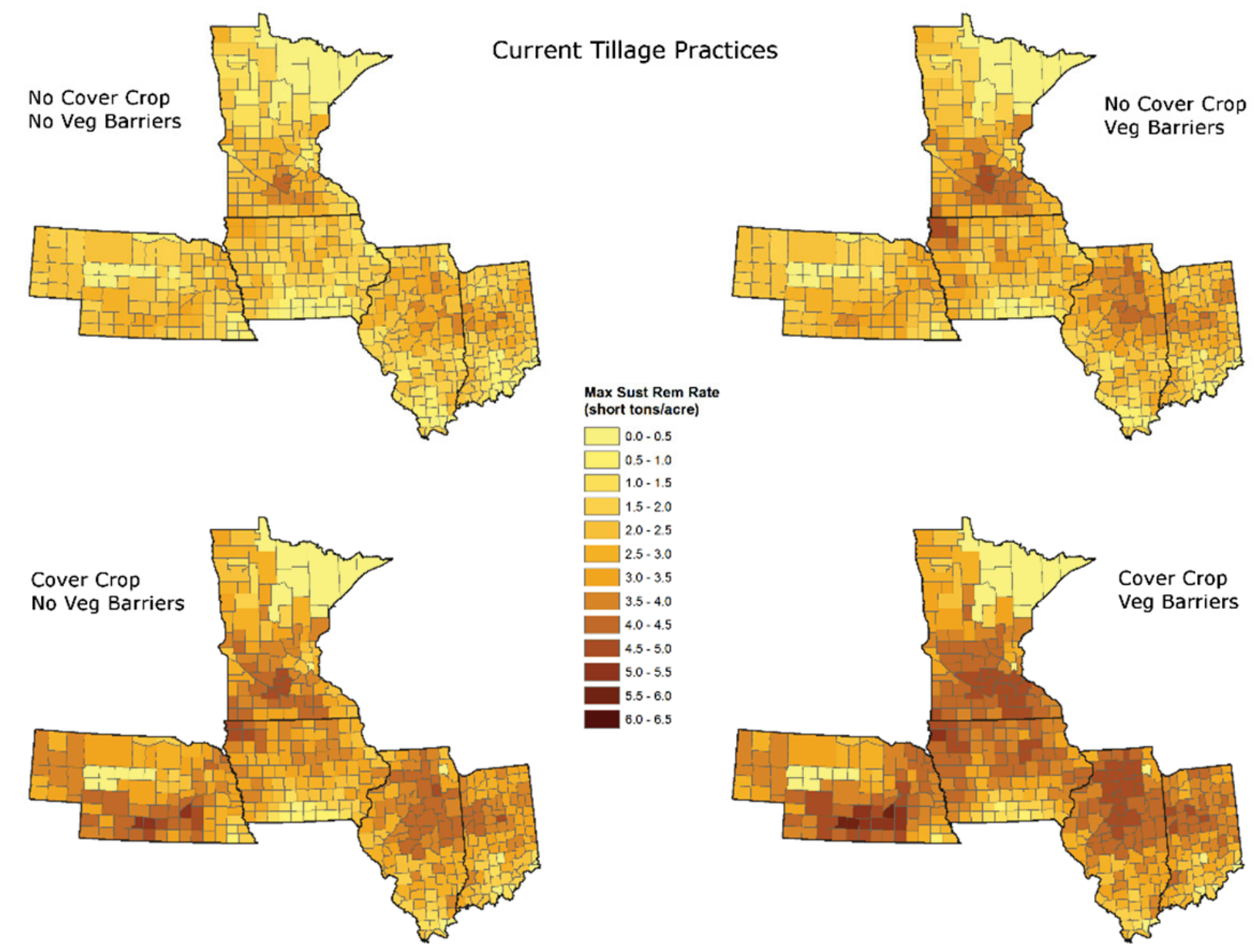

Figure 3. LEAF generated maximum sustainable corn stover removal rates using methodology described in Muth et al., 2012 for current tillage management practices. Includes top five residue producing states and scenarios using cover crop and vegetative barrier management strategies. 


\section{YU. Idaho Nationd labordory}

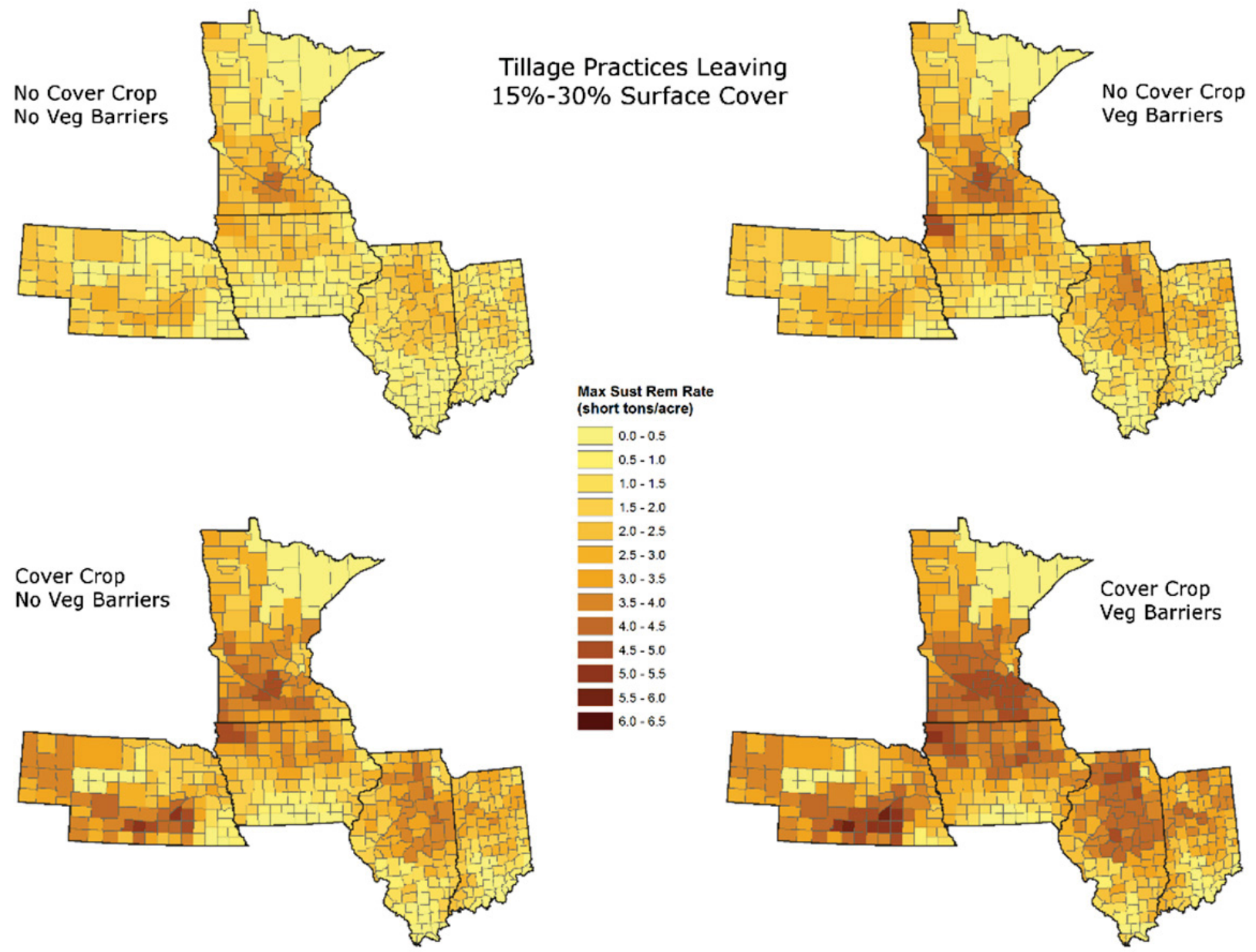

Figure 4. LEAF generated maximum sustainable corn stover removal rates using methodology described in Muth et al., 2012 for tillage management practices that leave approximately $15 \%-30 \%$ residue cover. Includes top five residue producing states and scenarios using cover crop and vegetative barrier management strategies. 

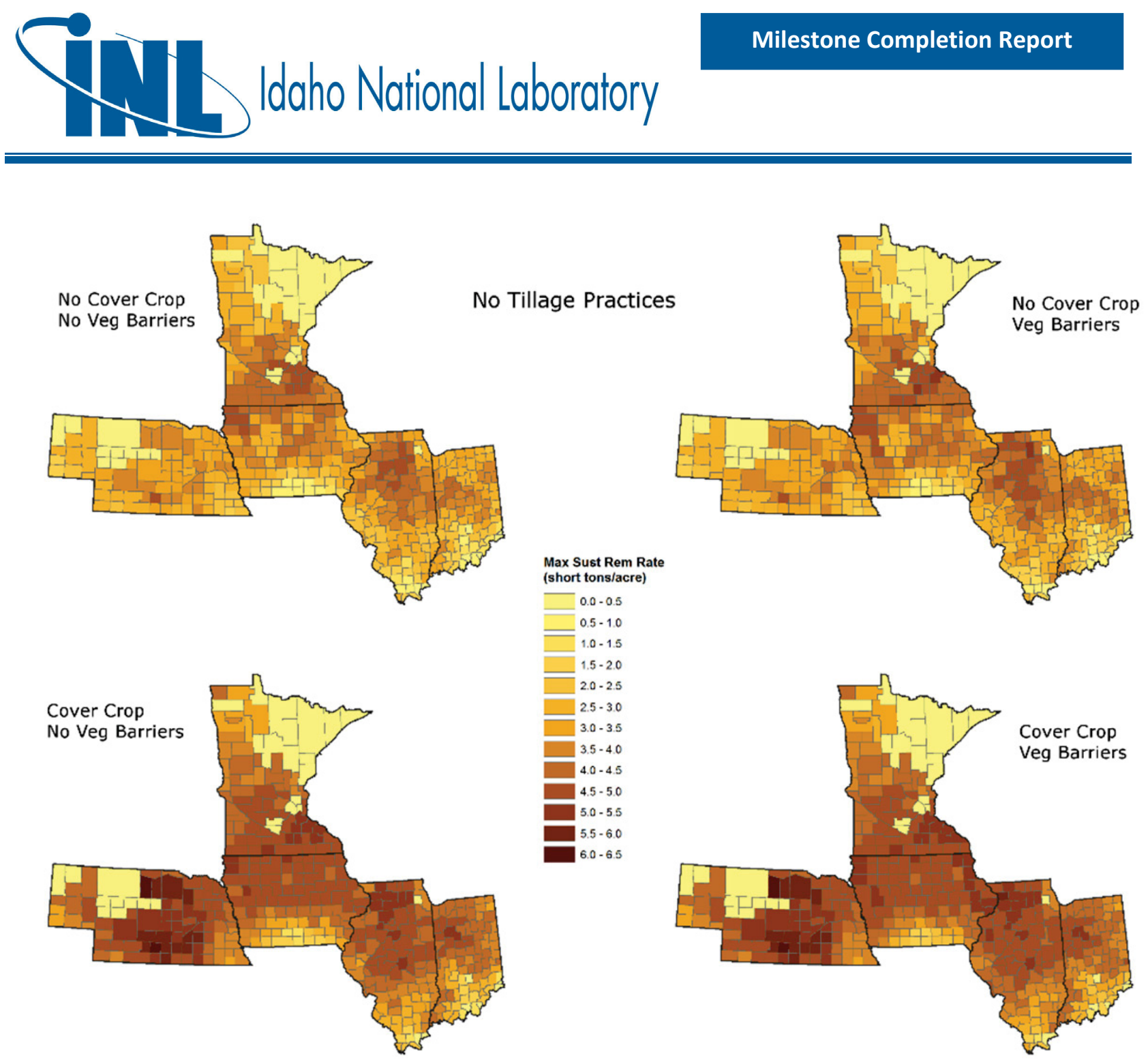

Figure 5. LEAF generated maximum sustainable corn stover removal rates using methodology described in Muth et al., 2012 for no tillage management practices. Includes top five residue producing states and scenarios using cover crop and vegetative barrier management strategies. 


\section{Target: Increase SMAF soil quality scores by $5 \%$ while maintaining BTU projected residue removal rates.}

This second target for agricultural residue pathways provides an opportunity to achieve economically viable residue removal rates while improving soil quality. This target infers that the SMAF soil quality score can be improved $5 \%$ through a reduction of soil erosion to less than $1 / 2$ the T-value, or tolerable soil loss, for a given soil, and also by increasing soil organic matter levels by $5 \%$. The analysis required to establish this target leverages the erosion impacts calculated as part of the data in Figures 3-5. Further demonstration requires the subfield perspectives shown in Figure 6 and Figure 7. Figure 6 provides a high resolution assessment of a standard Midwest row crop production field. Achieving soil loss below $1 / 2$ T-value in this field requires soil erosion levels less than 350 short tons annually. As shown in Figure 6 employing cover crop, no tillage, and variable rate residue removal strategies easily achieves erosion rates below $1 / 2 T$-value. The previous analysis shows that for the top five residue producing states the use of the Billion Ton Update removal rates shown Table 4 with the cover crop, vegetative barrier, and no tillage management strategies will achieve erosion rates less than $1 / 4 \mathrm{~T}$-value.

The other component of this target is increasing the soil organic matter by $5 \%$. Figure 7 provides an analysis of representative Midwest soils analyzed for long term organic matter impact of Billion Ton Update level removal rates under cover crop and no tillage management strategies. This analysis shows that residue removal performed in conjunction with cover crops and no tillage can increase soil organic matter 6\%-10\%. This data is currently being validated with Regional Feedstock Partnership field trial data and early results show that these gains are attainable. 


\section{Idaho National Laboratory}

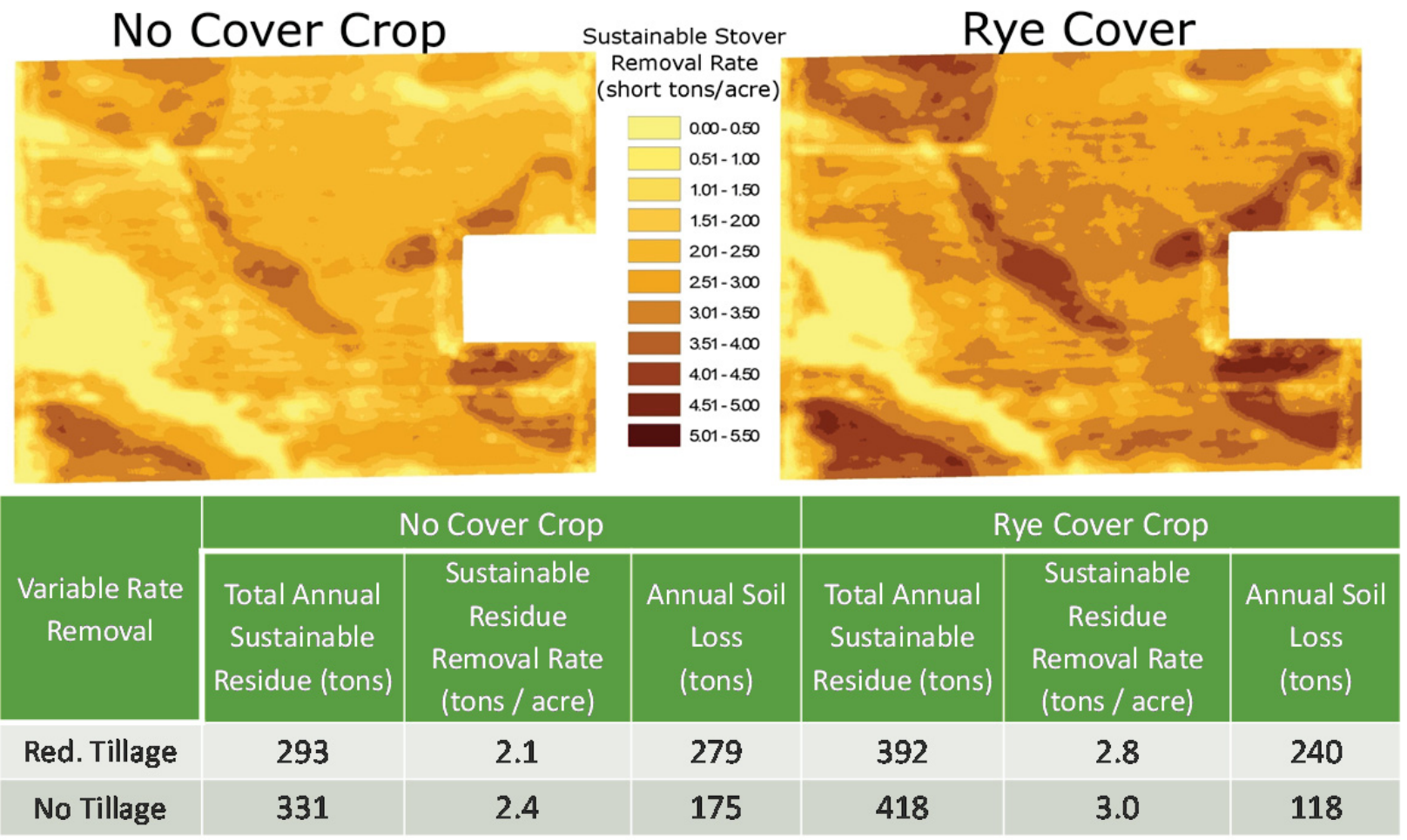

Figure 6. Field scale sustainable removal rate and soil erosion impacts of cover crop and no tillage management strategies.

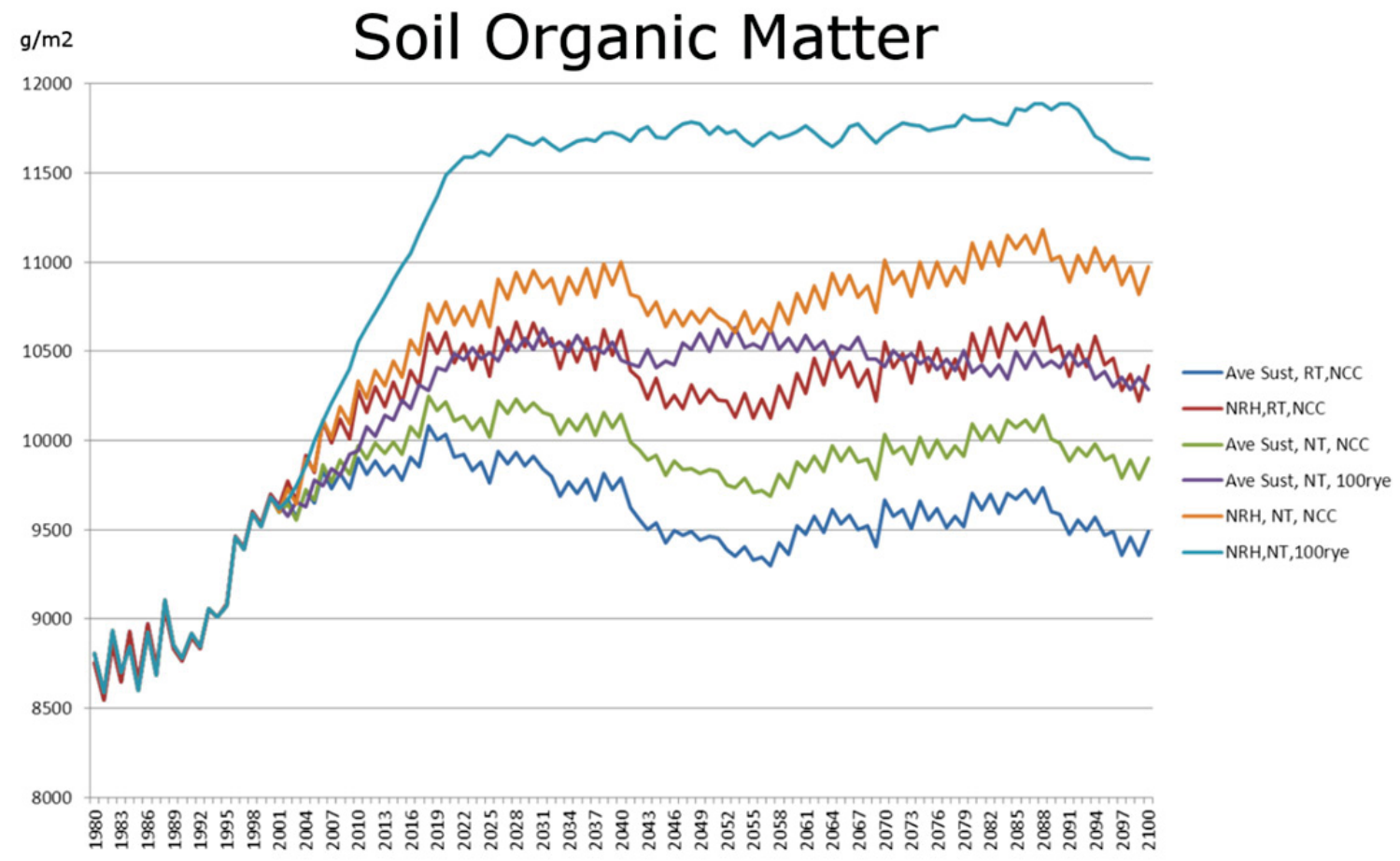

Figure 7. Long term SOC change as a result of different management practices shown in Figures 3-6. 
Target: Increase SMAF soil quality scores by $10 \%$ by integrating energy crops into the productive row crop landscape.

The analysis supporting this target is again focused on the primary soil erosion and soil organic matter metrics. It is well established that perennial crops reduce erosion to very low levels, so the primary focus in the following analysis is on the potential increase in soil organic matter from dedicated energy crops. Figure 8 shows the county average soil organic matter change (represented through the soil organic carbon [SOC] fraction) simulated from 2009-2030 for four primary potential energy crops. Short rotation woody crops (SRWC) and energy sorghum are included in these analyses, but the target has been established with a focus on perennial grasses with switchgrass and miscanthus as the representative crops in the following assessment.
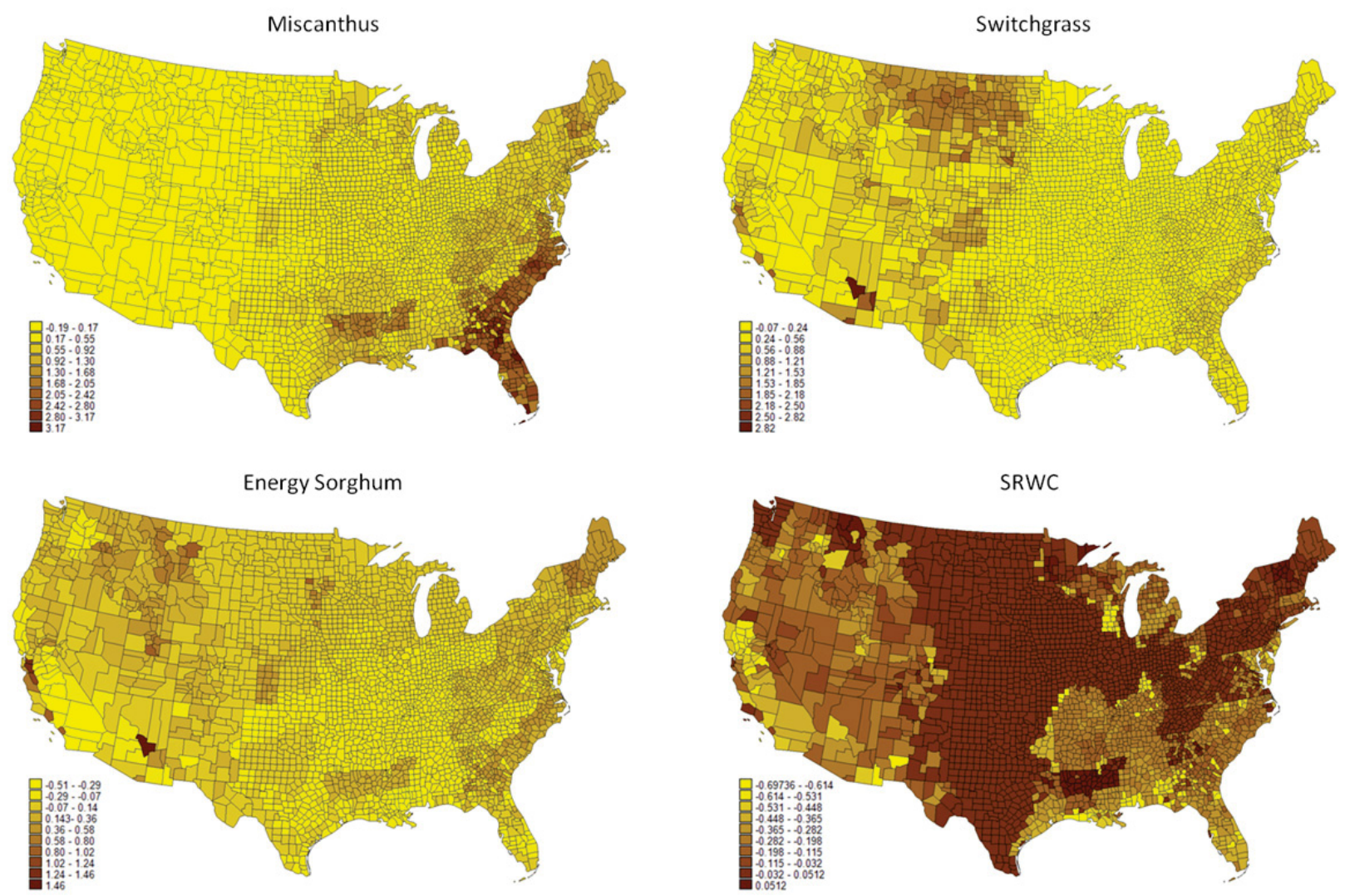

Figure 8. The SOC change projected for each dedicated energy crop from 2009-2030 in each county is displayed (\%/100). 


\section{Case Studies}

USDA Land Resource Regions

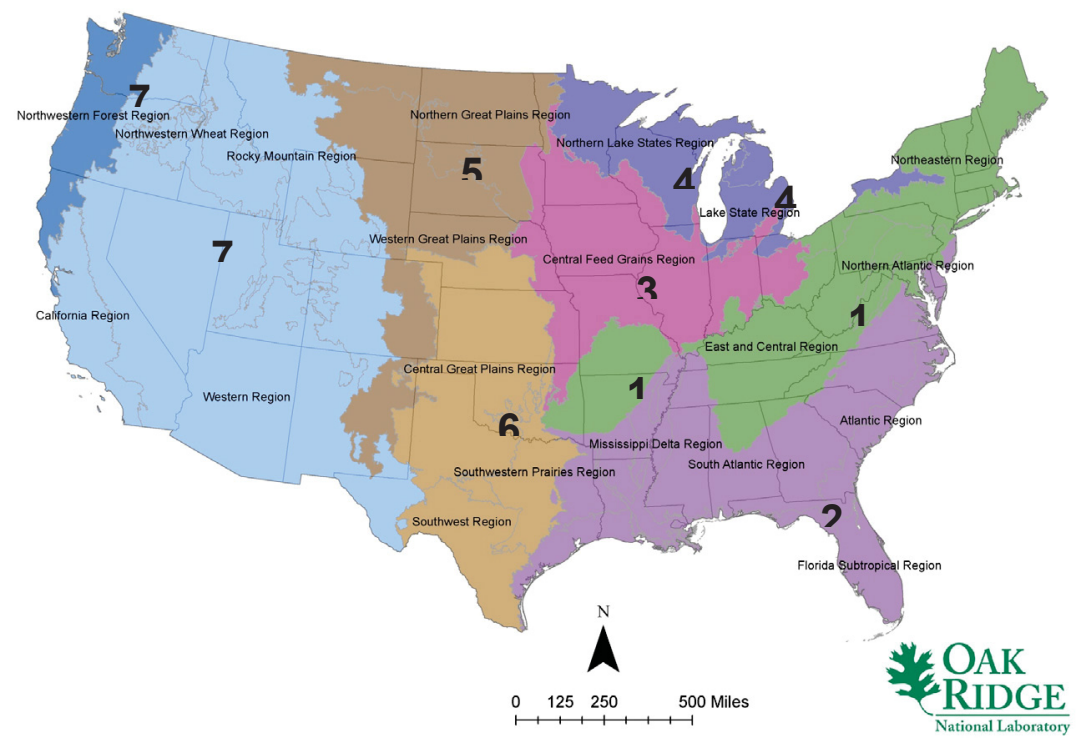

Switchgrass Sorghum Mixed Energycane Miscanthus

\begin{tabular}{cccccc}
\hline Zone 1 & $5-10$ & $6-12$ & $0.5-5$ & $0-12$ & $2-16$ \\
\hline Zone 2 & $5-12$ & $8-14$ & $5-12$ & $15-16$ & $4-16$ \\
\hline Zone 3 & $3-8$ & $9-13$ & $3-8$ & 0 & $4-16$ \\
\hline Zone 4 & $2-6$ & $0-8$ & $2-6$ & 0 & $2-12$ \\
\hline Zone 5 & $2-6$ & $0-6$ & $2-6$ & 0 & $1-5$ \\
\hline Zone 6 & $3-13$ & $8-9$ & $3-13$ & 7-8 & (coast 10-16) \\
\hline Zone 7 & & & & $10-16$ \\
\hline
\end{tabular}

Figure 9. Case study regions and documented yield ranges.

Ten sites were selected as case studies for assessing the potential SOC impact of introducing dedicated energy crop species across the regions identified in Figure 9. The LEAF toolset was used for the analysis with the DAYCENT model integrated as the $\mathrm{C}$ and $\mathrm{N}$ cycle model. The DAYCENT plant growth module was verified to produce yields within the ranges specified for each region in Figure 9. The ten sites are as follows:

Region 1: University Park - PA, Knoxville-TN

Region 2: Starkville - MS, Florence - SC

Region 3: Ames - IA

Region 4: Northern Wisconsin

Region 5: Bristol - SD

Region 6: College Station - TX

Region 7: Moccasin - MT, Corvallis - OR 


\section{Idaho National laboratory}

The DAYCENT model uses a historical spin-up over several hundred years at each site to establish SOC dynamically at the start of a simulated management scenario. The spin-up scenarios are typically represented by the native vegetative production (e.g. tall grass prairie, or deciduous forest) for each site and region up to the 1850 - 1900 timeframe. Historical productivity statistics (NASS, or other literature sources) were then used to represent agriculture up through 1970. Higher fidelity NASS statistics were then used from 1970-1990 to determine a single representative crop rotation. From 1990 to 2008 the NASS production numbers were reviewed to select an updated representative convention scenario. These rotations were then modeled through 2030 with DAYCENT for assessment against potential energy crops. Yields were assumed constant for this initial assessment through 2030. Descriptions of each of these conventional rotations are included in Tables 5-11. Comprehensive descriptions of vegetative production history used in the model will be added to the quarter 4 report after further cross checking and refining of site histories.

\section{SOC Projections in Dedicated Energy Crop Systems}

The yields for each of the dedicated energy crop species investigated in this analysis were simulated with the DAYCENT models plant growth module. For this initial assessment, the above ground biomass yields were verified to fall within the baseline yield ranges presented in Figure 9. More comprehensive yield based assessment will be performed next quarter. Nitrogen application was modeled for each crop at the levels described previously for nutrient use efficiency. The perennial crops were assumed to be 6 year productive stands with moderate tillage and replanting for stand reestablishment. The annual energy sorghum was modeled as a continuous rotation for this initial analysis and included a mild tillage operation in the spring. All regions implementing dedicated herbaceous perennial energy crops showed significant potential for increasing SOC by greater than $10 \%$ (Figure 8 ) as compared to conventional production systems. These projections are assuming static yields for conventional and dedicated energy crops over the 2008-2030 modeled timeframe. The annual species energy sorghum demonstrates potential for SOC increase at select case study sites. Due to more intensive management practices, energy sorghum does not demonstrate targeted SOC increase potential at sites in regions 1, 3, 6, 7. Energy sorghum was not modeled in regions 4 \& 5 due to low yield projections.

The following discussion presents the initial modeled SOC results for each site and region. Tables 5-11 provide the site specific run summary information. For each site the management scenarios are listed starting with NASS statistic determined conventional rotation, then moving through the modeled dedicated energy crop rotations. A brief description of each management is included. The 2008 modeled baseline SOC is then listed. This is modeled using the site specific spin-up for each location. Further analysis will include a calibration of each baseline SOC number with the field trial sites and NCSS SSL. Each of the conventional and dedicated energy crop managements are then modeled through 2030 allowing DAYCENT's crop growth module to project the yields. Energy crop yields were verified to fall within the range presented in Figure 9 for each region. The final two columns of each table represent the percentage change in SOC from the 2008 baseline and the \% change in SOC compared to the convention rotations, respectively. 


\section{Idaho National Laboratory}

Region 1: The modeled sites for this region are in Pennsylvania and Tennessee. The spin-up scenarios for the model are primarily native deciduous forests. For the Pennsylvania site, the commercial agricultural production was modeled using NASS statistics where available and literature sources starting in 1851 as a two year spring wheat/winter wheat rotation followed by a three year alfalfa stand. Starting in 1980 NASS statistics were reviewed developing the conventional rotation below, corn into three years of alfalfa through 2008. Projected out to 2030 , the conventional system is modeled as increasing SOC by $2.9 \%$. Relative to performance of the conventional system, energy sorghum increases SOC by $2.1 \%$ falling short of the $10 \%$ goal. Switchgrass and miscanthus modeled as six year stands each vastly exceed the $10 \%$ SOC increase goal.

Commercial agricultural production in Tennessee began in 1851 with a three year corn, one year spring wheat/winter wheat rotation. In the mid-1900's the rotation transitioned to a two year corn, spring wheat/winter wheat, four year alfalfa stand and eventually to a five year alfalfa stand by the end of the century. The Tennessee site conventional system through 2030 was modeled as a continuous five year alfalfa rotation. Energy sorghum again fell short of the 10\% SOC increase goal, while switchgrass and miscanthus increased SOC by $21.5 \%$ and $51.1 \%$ respectively.

Table 5. Region 1 Case Study Sites

\begin{tabular}{|c|c|c|c|c|c|}
\hline \multicolumn{6}{|c|}{ University Park, PA: Penn State University } \\
\hline Management & Description & $\begin{array}{l}2008 \text { Modeled } \\
\mathrm{SOC} \mathrm{g/m2} \mathrm{-} \\
20 \mathrm{~cm} \text { depth }\end{array}$ & $\begin{array}{l}2030 \text { Modeled } \\
\mathrm{SOC} \mathrm{g/m2} \mathrm{-} \\
20 \mathrm{~cm} \text { depth }\end{array}$ & $\begin{array}{l}\text { \% Change } \\
\text { from } \\
\text { Baseline }\end{array}$ & $\begin{array}{c}\text { \% Change } \\
\text { from } \\
\text { Conv. }\end{array}$ \\
\hline $\begin{array}{c}\text { Conventional } \\
\text { Rotation }\end{array}$ & Corn, 3 year hay stand rotation & 6495.2 & 6681.6 & 2.9 & N/A \\
\hline Energy Sorghum & $\begin{array}{l}1 \text { year rotation, } \mathrm{N} \text { application of } \\
90 \mathrm{lb} / \mathrm{acre} \text { annually }\end{array}$ & 6495.2 & 6819.6 & 5.0 & 2.1 \\
\hline Switchgrass & $\begin{array}{l}6 \text { year stand, } \mathrm{N} \text { application of } 90 \\
\mathrm{Ib} / \text { acre annually }\end{array}$ & 6495.2 & 7621.7 & 17.3 & 14.1 \\
\hline Miscanthus & 6 year stand & 6495.2 & 9068.1 & 39.6 & 35.7 \\
\hline \multicolumn{6}{|c|}{ Knoxville, TN: University of Tennessee } \\
\hline $\begin{array}{c}\text { Conventional } \\
\text { Rotation }\end{array}$ & 5 year hay stand rotation & 6626.0 & 6468.6 & -2.4 & N/A \\
\hline Energy Sorghum & $\begin{array}{c}1 \text { year rotation, } \mathrm{N} \\
\text { application of } 90 \mathrm{lb} / \text { acre } \\
\text { annually }\end{array}$ & 6626.0 & 6721.4 & 1.4 & 3.9 \\
\hline Switchgrass & $\begin{array}{c}6 \text { year stand, } \mathrm{N} \\
\text { application of } 90 \mathrm{lb} / \text { acre } \\
\text { annually }\end{array}$ & 6626.0 & 7860.2 & 18.6 & 21.5 \\
\hline Miscanthus & 6 year stand & 6626.0 & 9774.8 & 47.5 & 51.1 \\
\hline
\end{tabular}




\section{Idaho National Laboratory}

Region 2: The modeled sites for this region are in Mississippi and South Carolina. The spin-up scenarios for the sites in this region were also native deciduous forests. For the Mississippi site, commercial agricultural production began in 1851 with a strict annual cotton rotation which continued up until 1950 . Through the next couple decades corn and soybeans were added to the cotton rotation and by 1970 soybeans emerged as the primary crop. The Mississippi conventional system was modeled through 2030 as a one year soybean rotation. The SOC with the conventional system continued to decrease with a net loss of $9.4 \%$. Relative to the conventional system, energy sorghum, switchgrass, and miscanthus all exceeded the $10 \%$ goal with increases of SOC by $12.6 \%, 31.6 \%$, and $72.6 \%$ respectively.

For the South Carolina site, commercial agricultural production began 1851 with an annual corn rotation and continued until 1970. Over the next couple decades a corn, two year soybean rotation was modeled and by the end of the century an annual soybean rotation was simulated. This rotation was projected out to 2030 showed a decrease of SOC by $2 \%$. Simulated energy crops produced similar results achieved by the Mississippi site relative to the conventional system. Energy sorghum, switchgrass, and miscanthus resulted in SOC increases beyond the $10 \%$ goal at $12.9 \%, 27.9 \%$, and $78.6 \%$.

Table 6. Region 2 Case Study Sites

\begin{tabular}{|c|c|c|c|c|c|}
\hline \multicolumn{6}{|c|}{ Starkville, MS: Mississippi State University } \\
\hline Management & Description & $\begin{array}{l}2008 \text { Modeled } \\
\text { SOC g/m2 - } \\
20 \mathrm{~cm} \text { depth }\end{array}$ & $\begin{array}{l}2030 \text { Modeled } \\
\text { SOC g/m2 - } \\
20 \mathrm{~cm} \text { depth }\end{array}$ & $\begin{array}{c}\% \text { Change } \\
\text { from } \\
\text { Baseline }\end{array}$ & $\begin{array}{c}\text { \% Change } \\
\text { from } \\
\text { Conv. }\end{array}$ \\
\hline $\begin{array}{l}\text { Conventional } \\
\text { Rotation }\end{array}$ & $\begin{array}{l}1 \text { year soybean rotation, } \mathrm{N} \text { application } \\
\text { of } 22 \mathrm{lb} / \text { acre }\end{array}$ & 5466.1 & 4954.3 & -9.4 & N/A \\
\hline Energy Sorghum & $\begin{array}{l}1 \text { year rotation, } \mathrm{N} \text { application of } 90 \\
\mathrm{lb} / \text { acre annually }\end{array}$ & 5466.1 & 5580.1 & 2.1 & 12.6 \\
\hline Switchgrass & $\begin{array}{l}6 \text { year stand, } \mathrm{N} \text { application of } 90 \\
\mathrm{lb} / \text { acre annually }\end{array}$ & 5466.1 & 6521.8 & 19.3 & 31.6 \\
\hline Miscanthus & 6 year stand & 5466.1 & 8550.0 & 56.4 & 72.6 \\
\hline \multicolumn{6}{|c|}{ Florence, SC: Clemson University } \\
\hline $\begin{array}{c}\text { Conventional } \\
\text { Rotation }\end{array}$ & $\begin{array}{l}1 \text { year soybean rotation, } \mathrm{N} \text { application } \\
\text { of } 33 \mathrm{lb} / \text { acre }\end{array}$ & 3949.5 & 3870.4 & -2.0 & N/A \\
\hline Energy Sorghum & $\begin{array}{l}1 \text { year rotation, } \mathrm{N} \text { application of } 90 \\
\mathrm{lb} / \text { acre annually }\end{array}$ & 3949.5 & 4369.9 & 10.6 & 12.9 \\
\hline Switchgrass & $\begin{array}{l}6 \text { year stand, } \mathrm{N} \text { application of } 90 \\
\mathrm{Ib} / \text { acre annually }\end{array}$ & 3949.5 & 4950.0 & 25.3 & 27.9 \\
\hline Miscanthus & 6 year stand & 3949.5 & 6914.5 & 75.1 & 78.7 \\
\hline
\end{tabular}


Region 3: This region consists of a site in lowa with a spin-up that includes a prairie grass with simulated grazing up through 1900. Initial conventional system rotations modeled consisted of a two corn, three alfalfa stand through the mid-1900's. From 1950 through 2008 a corn, soybean rotation was modeled and this rotation was projected through 2030. With anticipated higher yield production this conventional system showed a slight increase of SOC by $0.9 \%$. Energy sorghum simulated for this site performed poorly relative to the conventional system decreasing SOC by $5.3 \%$. Switchgrass and miscanthus modeled as six year stands exceeded the $10 \%$ goal increasing SOC by $25.9 \%$ and $63.3 \%$ respectively.

Table 7. Region 3 Case Study Site

\begin{tabular}{|c|c|c|c|c|c|}
\hline \multicolumn{6}{|c|}{ Ames, IA: lowa State University } \\
\hline Management & Description & $\begin{array}{l}2008 \text { Modeled } \\
\text { SOC g/m2 - } \\
20 \mathrm{~cm} \text { depth }\end{array}$ & $\begin{array}{l}2030 \text { Modeled } \\
\text { SOC g/m2 - } \\
20 \mathrm{~cm} \text { depth }\end{array}$ & $\begin{array}{c}\% \text { Change } \\
\text { from } \\
\text { Baseline }\end{array}$ & $\begin{array}{c}\text { \% Change } \\
\text { from } \\
\text { Conv. }\end{array}$ \\
\hline $\begin{array}{l}\text { Conventional } \\
\text { Rotation }\end{array}$ & $\begin{array}{l}2 \text { year rotation corn/soybean rotation, } \\
\mathrm{N} \text { application of } 140 \mathrm{lb} / \text { acre on corn }\end{array}$ & 3082.0 & 3110.2 & 0.9 & N/A \\
\hline $\begin{array}{l}\text { Energy } \\
\text { Sorghum }\end{array}$ & $\begin{array}{l}1 \text { year rotation, } \mathrm{N} \text { application of } 90 \\
\mathrm{Ib} / \text { acre annually }\end{array}$ & 3082.0 & 2946.8 & -4.4 & -5.3 \\
\hline Switchgrass & $\begin{array}{c}6 \text { year stand, } \mathrm{N} \text { application of } 90 \\
\mathrm{Ib} / \text { acre annually }\end{array}$ & 3082.0 & 3916.7 & 27.1 & 25.9 \\
\hline Miscanthus & 6 year stand & 3082.0 & 5077.6 & 64.7 & 63.3 \\
\hline
\end{tabular}

Region 4: A site in northern Wisconsin was modeled for this region. The spin-up for this site modeled prairie grass up through 1900. NASS statics indicated that through the twenty century that alfalfa was the primary agricultural crop for the site and was modeled as a 5 year stand. This was conventional system was projected to 2030 and resulted in a SOC decrease of less than .14\%. Miscanthus modeled for this site as a six year stand showed great potential increasing SOC by $53 \%$.

Table 8. Region 4 Case Study Site

\begin{tabular}{|c|c|c|c|c|c|}
\hline \multicolumn{6}{|c|}{ Northern Wisconsin } \\
\hline Management & Description & $\begin{array}{l}2008 \text { Modeled } \\
\mathrm{SOC} \mathrm{g/m2} \mathrm{-} \\
20 \mathrm{~cm} \text { depth }\end{array}$ & $\begin{array}{l}2030 \text { Modeled } \\
\mathrm{SOC} \mathrm{g/m2} \mathrm{-} \\
20 \mathrm{~cm} \text { depth }\end{array}$ & $\begin{array}{c}\text { \% Change } \\
\text { from } \\
\text { Baseline }\end{array}$ & $\begin{array}{c}\text { \% Change } \\
\text { from } \\
\text { Conv. }\end{array}$ \\
\hline $\begin{array}{c}\text { Conventional } \\
\text { Rotation }\end{array}$ & 5 year hay stand rotation & 4442.8 & 4436.8 & -0.1 & $\mathrm{~N} / \mathrm{A}$ \\
\hline Miscanthus & 6 year stand & 4442.8 & 6791.3 & 52.9 & 53.1 \\
\hline
\end{tabular}




\section{Idaho National Laboratory}

Region 5: The modeled site for this region was in South Dakota. The spin-up for this site simulated prairie grass with occasionally grazing throughout each year up until 1900. Modeled commercial agricultural production beginning the following year had a rotation consisting of spring wheat, two years oats, two years corn, two years barley, and three year alfalfa stand. NASS statistics indicated that by 1950 the primary rotation included three year spring wheat, one year corn, and a three year alfalfa stand. This rotation continues for the following three decades before changing to a corn, soybean, spring wheat, soybean, three year alfalfa stand rotation. This conventional system is projected out to 2030 and showed a SOC decrease of $0.74 \%$. A six year switchgrass stand modeled on the same site showed great potential resulting in a $53.3 \%$ increase of SOC

Table 9. Region 5 Case Study Site

\begin{tabular}{|c|c|c|c|c|c|}
\hline \multicolumn{6}{|c|}{ Bristol, SD: South Dakota State University } \\
\hline Management & Description & $\begin{array}{l}2008 \text { Modeled } \\
\text { SOC g/m2 - } \\
20 \mathrm{~cm} \text { depth }\end{array}$ & $\begin{array}{l}2030 \text { Modeled } \\
\text { SOC g/m2 - } \\
20 \mathrm{~cm} \text { depth }\end{array}$ & $\begin{array}{c}\% \text { Change } \\
\text { from } \\
\text { Baseline }\end{array}$ & $\begin{array}{c}\text { \% Change } \\
\text { from } \\
\text { Conv. }\end{array}$ \\
\hline $\begin{array}{l}\text { Conventional } \\
\text { Rotation }\end{array}$ & $\begin{array}{l}7 \text { year spring wheat, soybean, corn, } \\
\text { soybean, } 3 \text { year hay stand rotation }\end{array}$ & 2647.9 & 2628.2 & -0.7 & N/A \\
\hline Switchgrass & $\begin{array}{c}6 \text { year stand, } \mathrm{N} \text { application of } 90 \mathrm{lb} / \text { acre } \\
\text { annually }\end{array}$ & 2647.9 & 4028.9 & 52.2 & 53.3 \\
\hline
\end{tabular}

Region 6: The site modeled in this region was in eastern Texas. The spin-up for this site included a prairie grass up until 1900. From 1901 through 1969 a three year, one year sorghum rotation was modeled followed by a decade of cotton, sorghum rotation. Through the last couple decade's corn was introduced into the rotation and the modeled conventional system took the form of cotton, corn, cotton, sorghum rotation. This system was projected out to 2030 and showed an increase in SOC by $5.8 \%$. Replacement of the conventional system with energy sorghum showed SOC decreasing by $12 \%$. Switchgrass and miscanthus both met the $10 \%$ goal with SOC increases of $12.6 \%$ and $87 \%$ respectively.

Table 10. Region 6 Case Study Site

\begin{tabular}{|c|c|c|c|c|c|}
\hline \multicolumn{6}{|c|}{ College Station, TX: Texas A\&M University } \\
\hline Management & Description & $\begin{array}{l}2008 \text { Modeled } \\
\text { SOC g/m2 - } \\
20 \mathrm{~cm} \text { depth }\end{array}$ & $\begin{array}{l}2030 \text { Modeled } \\
\text { SOC g/m2 - } \\
20 \mathrm{~cm} \text { depth }\end{array}$ & $\begin{array}{l}\% \text { Change } \\
\text { from } \\
\text { Baseline }\end{array}$ & $\begin{array}{c}\text { \% Change } \\
\text { from } \\
\text { Conv. }\end{array}$ \\
\hline $\begin{array}{l}\text { Conventional } \\
\text { Rotation }\end{array}$ & $\begin{array}{l}4 \text { year cotton/corn/cotton/sorghum } \\
\text { rotation, } \mathrm{N} \text { application of } \\
67 / 140 / 67 / 90 \mathrm{lb} / \text { acre respectively }\end{array}$ & 2512.3 & 2658.6 & 5.8 & N/A \\
\hline $\begin{array}{l}\text { Energy } \\
\text { Sorghum }\end{array}$ & $\begin{array}{l}1 \text { year rotation, } \mathrm{N} \text { application of } 90 \\
\mathrm{Ib} / \text { acre annually }\end{array}$ & 2512.3 & 2339.1 & -6.9 & -12.0 \\
\hline Switchgrass & $\begin{array}{c}6 \text { year stand, N application of } 90 \\
\text { Ib/acre annually }\end{array}$ & 2512.3 & 2992.7 & 19.1 & 12.6 \\
\hline Miscanthus & 6 year stand & 2512.3 & 4972.1 & 97.9 & 87.0 \\
\hline
\end{tabular}




\section{Idaho National Laboratory}

Region 7: The sites modeled in this region include Montana and Oregon. The spin-up modeled for Montana included prairie grass with an occasionally grazing throughout the year up until 1900. The following year commercial agricultural production was modeled with a spring wheat/winter rotation. This continued until 1960 where NASS statistics indicated a change for the next decade to barley/winter wheat, three year alfalfa stand with winter wheat at the end of the third year of the alfalfa stand. In 1970, the conventional system rotation added a spring wheat/winter wheat year to the previous system. This was modeled through 2008 and was projected forward through 2030. The conventional system showed an increase in SOC through 2030 of $1.7 \%$. A six year switchgrass stand modeled for this site showed SOC increases well beyond the established goal at $70.6 \%$

The spin-up for the Oregon site modeled native deciduous forests through 1900. From 1901 through 1968 a spring wheat/winter wheat rotation was simulated before moving to spring wheat/winter wheat, barley rotation and eventually to just a barley/winter wheat rotation. According to NASS statistics, in 1969 alfalfa become the primary agricultural crop and five year stands were modeled with winter wheat on the last year of the stand. This rotation was projected through 2030 and resulted in a $2.7 \%$ decrease of SOC. Energy sorghum modeled for this site fell short of the $10 \%$ goal at $4.7 \%$ while switchgrass exceeded the goal with $17.7 \%$ increase of SOC.

Table 11. Region 7 Case Study Sites

\begin{tabular}{|c|c|c|c|c|c|}
\hline \multicolumn{6}{|c|}{ Corvallis, OR: Oregon State University } \\
\hline Management & Description & $\begin{array}{c}2008 \text { Modeled } \\
\mathrm{SOC} \mathrm{g/m2} \mathrm{-} \\
20 \mathrm{~cm} \text { depth }\end{array}$ & $\begin{array}{c}2030 \text { Modeled } \\
\mathrm{SOC} \mathrm{g/m2} \mathrm{-} \\
20 \mathrm{~cm} \text { depth }\end{array}$ & $\begin{array}{c}\text { \% Change } \\
\text { from } \\
\text { Baseline }\end{array}$ & $\begin{array}{c}\text { \% Change } \\
\text { from } \\
\text { Conv. }\end{array}$ \\
\hline $\begin{array}{c}\text { Conventional } \\
\text { Rotation }\end{array}$ & $\begin{array}{l}5 \text { year hay stand, winter wheat (year } 5 \text { ) } \\
\text { rotation }\end{array}$ & 4827.6 & 4697.2 & -2.7 & $\mathrm{~N} / \mathrm{A}$ \\
\hline $\begin{array}{l}\text { Energy } \\
\text { Sorghum }\end{array}$ & $\begin{array}{c}1 \text { year rotation, } \mathrm{N} \text { application of } 90 \mathrm{lb} / \mathrm{acre} \\
\text { annually }\end{array}$ & 4827.6 & 4915.7 & 1.8 & 4.7 \\
\hline Switchgrass & $\begin{array}{c}6 \text { year stand, } \mathrm{N} \text { application of } 90 \mathrm{lb} / \mathrm{acre} \\
\text { annually }\end{array}$ & 4827.6 & 5528.1 & 14.5 & 17.7 \\
\hline \multicolumn{6}{|c|}{ Moccasin, MT: Montana State University } \\
\hline $\begin{array}{c}\text { Conventional } \\
\text { Rotation }\end{array}$ & $\begin{array}{l}2 \text { year spring wheat/winter wheat, } 3 \text { year } \\
\text { hay stand rotation }\end{array}$ & 3116.1 & 3169.4 & 1.7 & N/A \\
\hline Switchgrass & $\begin{array}{c}6 \text { year stand, } \mathrm{N} \text { application of } 90 \mathrm{lb} / \text { acre } \\
\text { annually }\end{array}$ & 3116.1 & 5405.8 & 73.5 & 70.6 \\
\hline
\end{tabular}

Additional perspective and opportunities can be found by integrating the agricultural residue and energy crop pathway targets. Specifically the use of perennial energy crops as the vegetative buffers in primary row crop production areas. Figure 10 shows an analysis where a switchgrass buffering management is used for a standard Midwest row crop production field. As seen in Figure 10 the switchgrass is placed on the landscape in areas where sustainability concerns currently exist. Figure 11 provides the 10 year soil carbon change from the management change in Figure 10. The impact is significant and easily achieves the target of a field scale SMAF score increase of $10 \%$. 


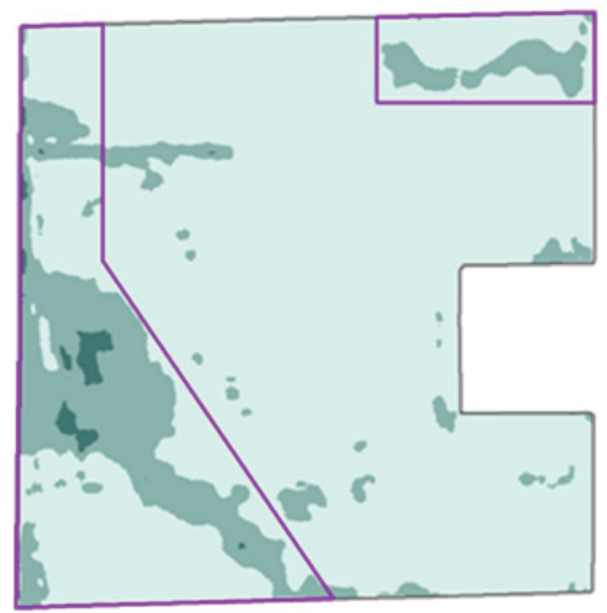

\section{Sustainability \\ Factors}

$\square$ Sustainable

$\mathrm{SCl}<0$

$\mathrm{SCl}<0$ \& Erosion $>\mathrm{T}$

Erosion $>\mathrm{T}$

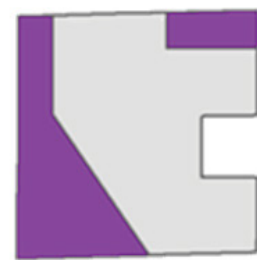

$\mathrm{CG} / \mathrm{SB}$

SWG

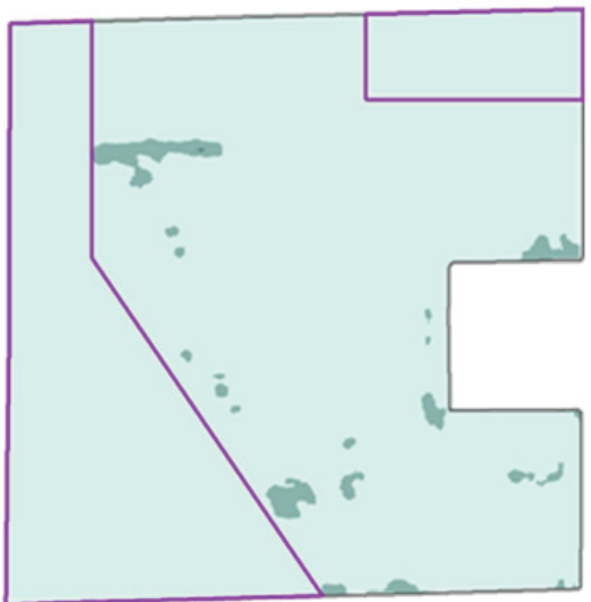

Figure 10. Field scale impacts of integrating dedicated energy crops into the primary row crop landscape.
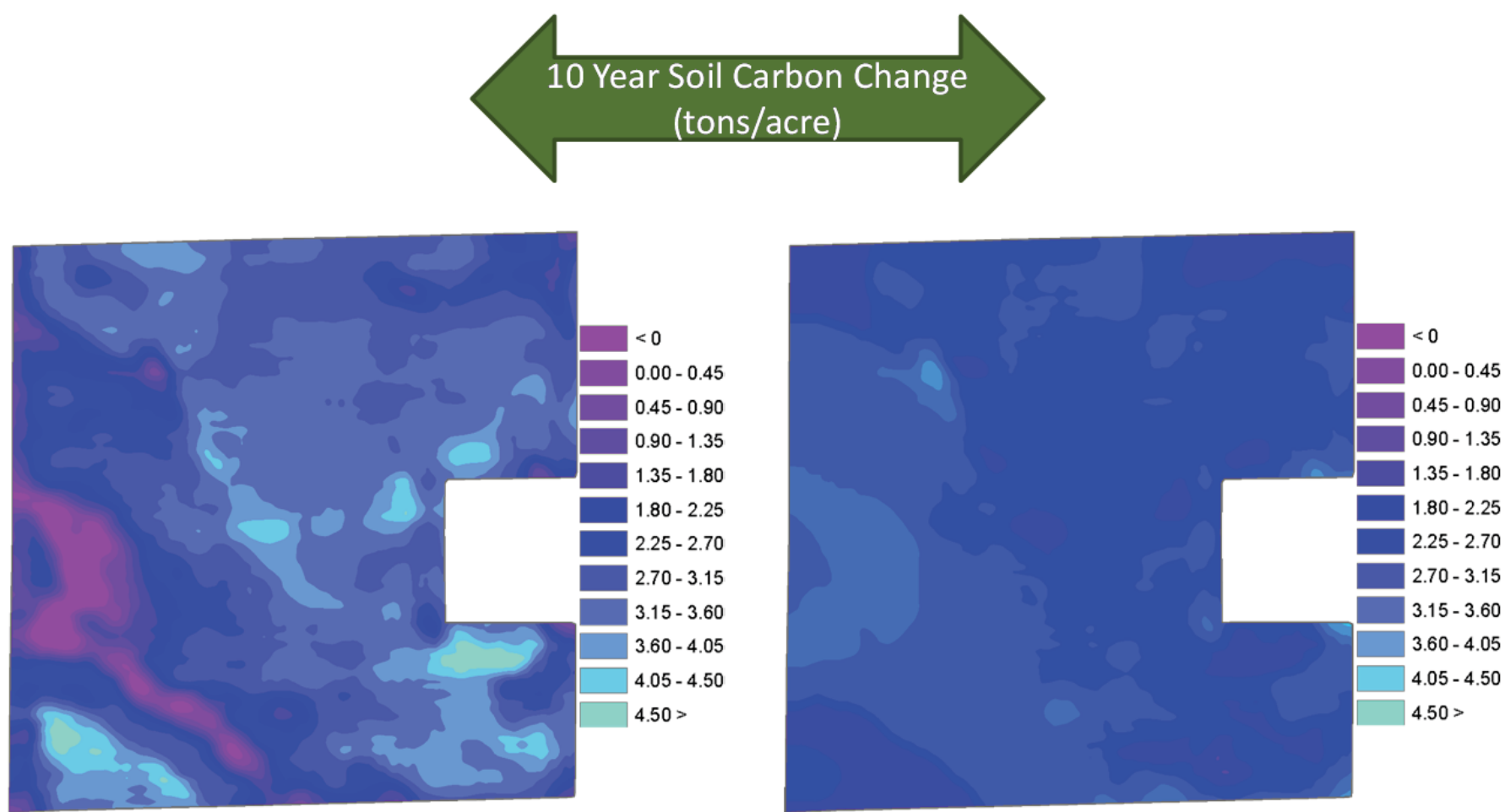

Figure 11. Field scale projection of ten year SOC change comparing conventional management practices and integrated landscape management strategies that include dedicated energy crops strategically placed in primary row crop production. 


\section{Summary and Conclusions}

This report achieved the FY13 BETO Sustainable Joule Dashboard Milestone: Determine metrics and set targets for soil quality on agriculture residue and energy crop pathways. The metrics were determined leveraging the extension collaboration through the DOE Biomass Regional Feedstock Partnership program. The soil quality metrics were aligned with the Soil Management Assessment Framework (SMAF). The comprehensive metrics within the SMAF were organized and prioritized into management driven metrics, primary metrics, and secondary metrics. Management driven metrics were not considered in the targets set through this report. The prioritization of metrics was driven by determining which metrics could be simulated across the management scenarios and geographic characteristics necessary for setting robust and meaningful targets. The primary metrics were determined to be soil erosion and soil organic carbon.

Two targets were established for agricultural residue pathways. The first target is to increase sustainable residue availability by $50 \%$ while maintaining current soil quality levels. The second targets achieving US Billion Ton Update residue collection levels while increasing soil quality to achieve a $5 \%$ increase in total SMAF score. For the second target the $5 \%$ increase in SMAF score was set by analytically verifying advanced management scenarios that reduce average erosion levels to $1 / 2$ of T-values (tolerable soil loss levels) and increase soil organic carbon levels by $5 \%$. The analyses supporting these targets focused on the top five residue producing states (lowa, Illinois, Nebraska, Minnesota, Indiana) in the US as identified by the US Billion Ton Update and Muth et al., 2012. Baseline (2012) sustainable residue removal levels for these five is 2.06 short tons/acre, with a total residue availability at 106 million tons annually. Three advanced management strategies were investigated: 1) cover crops, 2) vegetative barriers, and 3) no tillage. The analysis applying these three strategies increased the average sustainable removal rate to 4.32 short tons/acre for the five states. This increase is the basis for confidently establishing the target to increase residue availability by $50 \%$ while maintaining soil quality.

The second residue pathway target was set through the same five-state spatial analysis looking at the impact on soil erosion of implementing the three advanced management strategies, but simply maintaining the BTU baseline removal rates. The analysis showed that soil erosion was decreased to less than $1 / 4 \mathrm{~T}$-value. The other component of setting the second residue pathway target is achieving soil organic carbon increases of $5 \%$. Representative soils were used in conjunction with the advanced management strategies and BTU baseline removal rates. The analysis showed the potential to increase soil organic matter levels 6\%-10\%. These analysis results provided the technical basis for determining the second residue pathway target.

This report also determines metrics and sets targets for soil quality on energy crop pathways. The metrics used for the energy crop pathway are the same SMAF criteria as used for the residue pathway targets. The target for the energy crop pathway is to increase SMAF soil quality scores by $10 \%$ by integrating energy crops into the productive row crop landscape. The analysis approach for determining this target includes county level soil carbon modeling for four primary energy crops (switchgrass, miscanthus, energy sorghum, and short rotation woody crops modeled as willow). Detailed regional case studies set to couple with Regional Feedstock Partnership sites were also done to set this target. The results of the analysis showed that the perennial grasses have the potential increase soil organic carbon by $14 \%-78 \%$ across the sites and regions. The analysis also showed a large decrease in soil erosion. These factors were used to set the energy crop pathway target for soil quality. 


\section{References:}

Andrews, S., Karlen, D., Mitchell, J. 2002a. A comparison of soil quality indexing methods for vegetable production systems in Northern California. Agriculture, ecosystems \& environment, 90(1), 25-45.

Andrews, S.S., Karlen, D.L., Cambardella, C.A. 2004. The soil management assessment framework. Soil Science Society of America Journal, 68(6), 1945-1962.

Andrews, S.S., Mitchell, J.P., Mancinelli, R., Karlen, D.L., Hartz, T.K., Horwath, W.R., Pettygrove, G.S., Scow, K.M., Munk, D.S. 2002b. On-farm assessment of soil quality in California's central valley. Agronomy Journal, 94(1), 12-23.

Arshad, M., Lowery, B., Grossman, B. 1996. Physical tests for monitoring soil quality. Methods for assessing soil quality(methodsforasses), 123-141.

Baily, R.G. 1995. Description of the ecoregions of the United States. USDA Forest Service, Washington DC.

Blair, J.M., Bohlen, P.J., Freckman, D.W. 1996. Soil invertebrates as indicators of soil quality. Methods for assessing soil quality(methodsforasses), 273-291.

Bongers, T. 1990. The Maturity Index - an Ecological Measure of Environmental Disturbance Based on Nematode Species Composition. Oecologia, 83(1), 14-19.

Doran, J.W., Parkin, T.B. 1994. Defining and assessing soil quality. Defining soil quality for a sustainable environment(definingsoilqua), 1-21.

Elliott, E.T., Burke, I.C., Monz, C.A., Frey, S.D., Paustian, K.H., Collins, H.P., Paul, E.A., Cole, C.V., Blevins, R.L., Frye, W.W. 1994. Terrestrial carbon pools: preliminary data from the Corn Belt and Great Plains regions. Defining soil quality for a sustainable environment(definingsoilqua), 179-191.

English, A., W Tyner, J Sesmero, O Phillip, D Muth (2013), "Environmental Tradeoffs of Stover Removal and Erosion in Indiana," Biofuels, Bioproducts \& Biorefining, 7: 78-88.

Franzluebbers, A. 1999. Potential C and N mineralization and microbial biomass from intact and increasingly disturbed soils of varying texture. Soil Biology and Biochemistry, 31(8), 1083-1090.

Franzluebbers, A., Haney, R., Hons, F., Zuberer, D. 1996. Active fractions of organic matter in soils with different texture. Soil Biology and Biochemistry, 28(10), 1367-1372.

Gregorich, E., Monreal, C., Carter, M., Angers, D., Ellert, B. 1994. Towards a minimum data set to assess soil organic matter quality in agricultural soils. Canadian Journal of Soil Science, 74(4), 367-385.

Gregory, P.J., Simmonds, L.P., Pilbeam, C.J. 2000. Soil type, climatic regime, and the response of water use efficiency to crop management. Agronomy Journal, 92(5), 814-820.

Grossman, R., Harms, D., Kingsbury, D., Shaw, R., Jenkins, A. 2001a. Assessment of soil organic carbon using the US soil survey. Reprinted from, 87-104.

Grossman, R., Harms, D., Seybold, C., Herrick, J. 2001b. Coupling use-dependent and use-invariant data for soil quality evaluation in the United States. Journal of Soil and Water Conservation, 56(1), 63-68.

Hanson, B.R., Grattan, S.R. 1992. Agricultural Salinity and Drainage: Users Handbook. University of California.

Harris, R.F., Karlen, D.L., Mulla, D.J., Doran, J., Jones, A. 1996. A conceptual framework for assessment and management of soil quality and health. Methods for assessing soil quality., 61-82.

Havlin, J., Beaton, J., Tisdale, S., Nelson, W. 1999. Soil fertility and fertilizers: an introduction to nutrient management. Soil fertility and fertilizers: an introduction to nutrient management.(Ed. 6).

Jastrow, J. 1996. Soil aggregate formation and the accrual of particulate and mineral-associated organic matter. Soil Biology and Biochemistry, 28(4), 665-676.

Jones, C., Ratliff, L., Dyke, P. 1982. Estimation of potentially mineralizable soil nitrogen from chemical and taxonomic criteria 1. Communications in Soil Science \& Plant Analysis, 13(2), 75-86.

Karlen, D.L., Parkin, T.B., Eash, N.S., Doran, J., Jones, A. 1996. Use of soil quality indicators to evaluate conservation reserve program sites in lowa. Methods for assessing soil quality., 345-355. 


\section{Idaho National laboratory}

Karlen, D., D Muth, "Landscape Management for Sustainable Supplies of Bioenergy Feedstock and Enhanced Soil Quality," In-Press, Agrocencia.

Larson, W., Pierce, F. 1991. Conservation and enhancement of soil quality. Evaluation for sustainable land management in the developing world, 2(12), 175-203.

Linden, D.R., Hendrix, P.F., Coleman, D.C., van Vliet, P.C. 1994. Faunal indicators of soil quality. Defining soil quality for a sustainable environment(definingsoilqua), 91-106.

Lowery, B., Hickey, W.J., Arshad, M., Lal, R. 1996. Soil water parameters and soil quality. Methods for assessing soil quality(methodsforasses), 143-155.

Maas, E.V. 1990. Crop salt tolerance. in: Agricultural salinity assessment and management, (Ed.) K.K. Tanji, American Society of Civil Engineers. New York.

Maynard, D. 1997. Knott's handbook for vegetable production, John Wiley \& Sons, New York.

Muth, D., KM Bryden (2013) "An Integrated Model for Assessment of Sustainable Agricultural Residue Removal Limits for Bioenergy Systems," Environmental Modelling and Software, 39:50-69.

Muth, D., R Nelson, KM Bryden (2012) "Sustainable Agricultural Residue Removal for Bioenergy: A Spatially Comprehensive National Assessment," Applied Energy, doi:10.1016/j.apenergy.2012.07.028

Needelman, B., Wander, M., Bollero, G., Boast, C., Sims, G., Bullock, D. 1999. Interaction of Tillage and Soil Texture Biologically Active Soil Organic Matter in Illinois. Soil Science Society of America Journal, 63(5), 1326-1334.

NRCS 1: http://soils.usda.gov/sqi/publications/files/sq_two_1.pdf

NRCS 2: http://soils.usda.gov/sqi/management/files/sq_atn_7.pdf

Quisenberry, V., Smith, B., Phillips, R., Scott, H., Nortcliff, S. 1993. A soil classification system for describing water and chemical transport. Soil Science, 156(5), 306-315.

Rice, C.W., Moorman, T.B., Beare, M. 1996. Role of microbial biomass carbon and nitrogen in soil quality. Methods for assessing soil quality(methodsforasses), 203-215.

Seybold, C., Mausbach, M., Karlen, D., Rogers, H. 1998. Quantification of soil quality. Soil process and the carbon cycle. CRC Press London, 387-404.

Sharpley, A.N., Weld, J.L., Beegle, D.B., Kleinman, P., Gburek, W., Moore, P., Mullins, G. 2003. Development of phosphorus indices for nutrient management planning strategies in the United States. Journal of Soil and Water Conservation, 58(3), 137-152.

Sikora, L.J., Stott, D., Doran, J., Jones, A. 1996. Soil organic carbon and nitrogen. Methods for assessing soil quality., 157-167.

Smith, J.L., Doran, J.W., Jones, A. 1996. Measurement and use of $\mathrm{pH}$ and electrical conductivity for soil quality analysis. Methods for assessing soil quality., 169-185.

Sparling, G., Pankhurst, C., Doube, B., Gupta, V. 1997. Soil microbial biomass, activity and nutrient cycling as indicators of soil health. Biological indicators of soil health., 97-119.

Turco, R.F., Kennedy, A.C., Jawson, M.D. 1994. Microbial indicators of soil quality. Defining soil quality for a sustainable environment(definingsoilqua), 73-90.

USDA-NRCS. 1998. Keys to Soil Taxonomy 8th Ed. National Soil Survey Publication. Washington DC.

USDA-NRCS. 2001. Soil quality test kit guide. USDA-NRCS Soil Quality Institute, Ames, IA.

USDA-SCS. 1981. Land Resources Regions and Major Land Resource Areas of the United States. Agricultural Handbook No 296, US Government Print Office, Washington DC.

USDA. 1966. Aggregate stability of soils from western United States and Canada. Tech Bul. No. 1335. US Gov. Print Office, Washington DC.

U.S. Department of Energy. U.S. billion-ton update: biomass supply for a bioenergy and bioproducts industry. In: Perlack, R.D. and Stokes, B.J., leads. Report no.: ORNL/TM-2011/224. DOE ORNL. Contract no.: DE-AC05-00OR22725. Oak Ridge (TN): Oak Ridge National Laboratory; 2011. 
Whittaker, C.W., Anderson, M., Reitemeier, R. 1964. Liming soils: An aid to better farming.

Wolf, A.M., Baker, D. 1985. Comparisons of soil test phosphorus by Olsen, Bray P1, Mehlich I and Mehlich III methods 1. Communications in Soil Science \& Plant Analysis, 16(5), 467-484. 